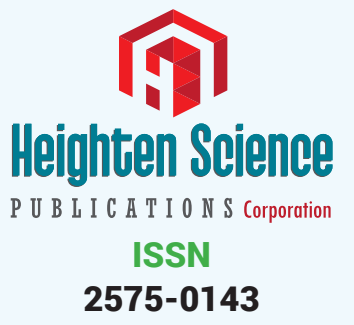

*Address for Correspondence: Victor Tsirkin, MD, Department of Normal Physiology, Kazan State Medical University, 420012, Kazan, Butlerov Street, 49, Russia, Tel: 8-912-377-57-74; Fax(833-2) 37-51-69; Email: tsirkin@list.ru

Submitted: 16 October 2018

Approved: 16 November 2018

Published: 19 November 2018

Copyright: @ 2018 Tsirkin V, et al. This is an open access article distributed under the Creative Commons Attribution License, which permits unrestricted use, distribution, and reproduction in any medium, provided the original work is properly cited

Keywords: Myocardium; Adrenaline; Histidine; Adrenergic blockers; Estrous cycle; Pregnancy

Abbreviations: AR: Adrenoceptors; beta-ARIM: beta-Adrenoceptor Inhibitory Mechanism; ESBAR Endogenous Sensitizer of beta- Adrenoceptors; HRV: Heart Rate Variability

Check for updates
Research Article

\section{Influence of Histidine on the} contractility and adrenaline inotropic effect in the experiments with myocardium of right ventricular of Non pregnant and Pregnant Rats

\author{
Victor Tsirkin ${ }^{1 *}$, Alexander Nozdachev ${ }^{2}$, Julia Korotaeva ${ }^{3}$ and \\ Grigory Khodyrev' \\ 'Department of biology and methods of teaching biology, Vyatka State University 610000, Kirov, \\ Russia and *Institute of Neuroscience of Kazan State Medical University, 420012, Kazan, Russia \\ ${ }^{2}$ Department of General Physiology, Saint-Pererburg State University, 199034, Saint-Pererburg, \\ Russia \\ ${ }^{3}$ Department of biology Kirov State Medical University, 610027, Kirov, Russia
}

\section{Abstract}

It was investigated contractility and adrenoreactivity of intact myocardium strips of right ventricular in experiment with 60 rats. They were assessed by the force of induce contraction and its changes under the influence of adrenaline $\left(10^{-9}\right.$ or $\left.10^{-5} \mathrm{~g} / \mathrm{ml}\right)$. Found that these indicators do not depend on the phases of the estrous cycle and the presence of pregnancy. Histidine $\left(10^{-10}\right.$ $\left.10^{-4} \mathrm{~g} / \mathrm{ml}\right)$ did not increase the response to adrenalin $\left(10^{-9} \mathrm{~g} / \mathrm{ml}\right)$, but increased the force of the contractions in rats in progesterone dominance (trend) and pregnancy (statistically significant). Against the background of propranolol $\left(10^{-8} \mathrm{~g} / \mathrm{mL}\right)$ or atenolol $\left(10^{-8}, 10^{-6} \mathrm{~g} / \mathrm{mL}\right)$, adrenaline $\left(10^{-5} \mathrm{~g}\right.$ $/ \mathrm{mL}$ ) instead of increasing the force of contraction reduced it (probably due to activation of beta ${ }_{3}$, alpha $_{1}$ - and alpha ${ }_{1}$ a2- adrenergic receptors), and histidine $\left(10^{-4} \mathrm{~g} / \mathrm{mL}\right)$ prevented this reduction, but does not restore full ability of adrenaline to exert a positive inotropic effect. On the background of nicergoline $\left(10^{-8} \mathrm{~g} / \mathrm{mL}\right.$ or nicergoline and propranolol $\left(10^{-8} \mathrm{~g} / \mathrm{mL}\right)$, adrenaline $\left(10^{-5} \mathrm{~g} / \mathrm{mL}\right)$ did not alter the force of contraction, and histidine $\left(10^{-4} \mathrm{~g} / \mathrm{mL}\right)$ restore ability of adrenaline to exert a positive inotropic effect but only in the experiments with nicergoline. Concluded that histidine increases the efficiency of the activation of all three (beta - , beta ${ }_{2}^{-}$and beta ${ }_{3}^{-}$) populations of myocardial beta-adrenoceptoprs, including at lower by adrenergic blockers. Therefore, histidine proposed as an antagonist of beta-adrenergic blockers and as resensitizator of these receptors.

Core Tip: In the experiments with strips of the right ventricle of 40 nonpregnant and 20 pregnant rats histidine $\left(10^{-10}-10^{-4} \mathrm{~g} / \mathrm{mL}\right)$ did not increase the response to adrenaline $\left(10^{-9} \mathrm{~g} / \mathrm{ml}\right)$, but increased the force of contractions in pregnant rats. On the background of propranolol $\left(10^{-8}\right.$ $\mathrm{g} / \mathrm{mL})$ or atenolol $\left(10^{-8}, 10^{-6} \mathrm{~g} / \mathrm{mL}\right)$, adrenaline $\left(10^{-5} \mathrm{~g} / \mathrm{mL}\right)$ showed a negative inotropic effect, and histidine $\left(10^{-4} \mathrm{~g} / \mathrm{mL}\right)$ prevented it, but does not restore the ability of adrenaline to show positive inotropic effect,. i.e histidine exhibits the properties of the antagonist of beta-blockers and of resensitizator of beta-adrenoceptors.

\title{
Introduction
}

Interest in the physiological role of histidine as a free amino acid increased after establishing its ability to enhance the effectiveness of activation beta $_{2}$-adrenoceptors (AR) of rat myometrium [1], which was confirmed in subsequent years [2,3], including under artificial reduction of activate of effectiveness of beta $_{2}$-AR by ozone [4], or lysophosphatidylcholine [5] or propranolol as blocker of beta -AR [5,6]. Histidine was originally considered as a possible component of endogenous sensitizer of beta-AR 
(ESBAR) [2,3], but then was assigned to the group of exogenous analogues of ESBAR $[5,6]$. In subsequent studies were initiated on the effect of histidine on contractility and adrenoreactivity of myocardium of animals $[7,8]$ and humans $[9,10]$. But they have given mixed results. Thus, in experiments with frog heart ventricle was shown [11], that histidine $\left(10^{-5} \mathrm{~g} / \mathrm{mL}\right)$ did not effect on its contractility, but increases the positive inotropic effect of adrenaline used at concentrations of $10^{-8}, 10^{-7}$ and $10^{-6} \mathrm{~g} / \mathrm{mL}$. However, Yu. Penkina et al. [7], in similar experiments with intact strips of frog ventricule revealed that the positive inotropic effect of adrenaline $\left(10^{-6} \mathrm{~g} / \mathrm{mL}\right)$ increases under the influence of histidine at a concentration of $10^{-8} \mathrm{~g} / \mathrm{mL}$, but not changes under histidine at a concentration $10^{-7}-10^{-4} \mathrm{~g} / \mathrm{mL}$. However histidine at concentrations of $10^{-4}$ and $10^{-3} \mathrm{~g}$ $/ \mathrm{ml}$, restored the ability of adrenaline $\left(10^{-6} \mathrm{~g} / \mathrm{ml}\right)$ have a positive inotropic effect which was reduced under the influence of lysophosphatidylcholine $\left(10^{-7} \mathrm{~g} / \mathrm{mL}\right)$. In experiments with intact strips of the right ventricle of the heart of nonpregnant rats (excluding the phase of the cycle) YA Penkina et al. [7] using histidine at three concentrations $\left(10^{-5}, 10^{-4}\right.$ and $10^{-3} \mathrm{~g} / \mathrm{mL}$ ) showed that at a concentration of $10^{-5} \mathrm{~g} / \mathrm{mL}$ adrenalin does not effect on myocardial contractility, and at the concentrations $10^{-4}$ and $10^{-3} \mathrm{~g} / \mathrm{mL}$ adrenaline increases at the same time in any of these concentrations histidine did not increase positive inotropic effect of adrenaline $\left(10^{-8}-10^{-6} / \mathrm{mL}\right)$, even in concentrations of $10^{-3} \mathrm{~g}$ / $\mathrm{mL}$ histidine exhibits beta-adrenoceptor blocking effect in relation to adrenaline $(10$ $\left.{ }^{6} \mathrm{~g} / \mathrm{mL}\right)$. However, in experiments with lysophosphatidylcholine $\left(10^{-5} \mathrm{~g} / \mathrm{mL}\right)$, which blocked the positive inotropic effect of adrenaline $\left(10^{-6} \mathrm{~g} / \mathrm{mL}\right)$, all three concentrations of histidine $\left(10^{-5}, 10^{-4}\right.$ and $\left.10^{-3} \mathrm{~g} / \mathrm{ml}\right)$ restores the ability of adrenaline exert a positive inotropic effect. KN Korotaeva and al $[9,10]$ in experiments with biopsies from the right eye patients undergoing aorto-coronary bypass heart using histidine at concentrations of $10^{-9}-10^{-4} \mathrm{~g} / \mathrm{mL}$, showed that at a concentration of $10^{-5} \mathrm{~g} / \mathrm{mL}$, it increases the force of contraction (up to $133 \%$ of background level), but it does not effect in the concentrations $10^{-9}, 10^{-7}$ and $10^{-4} \mathrm{~g} / \mathrm{mL}$. At the same time, the positive inotropic effect of adrenaline $\left(10^{-8} \mathrm{~g} / \mathrm{mL}\right)$ was not changed under the influence of histidine at concentrations $10^{-9}$ $10^{-7} \mathrm{~g} / \mathrm{mL}$, but it increased under the influence of histidine in $10^{-5}$ and $10^{-4} \mathrm{~g} / \mathrm{mL}$. The authors concluded that histidine is able to increase the efficiency activation of beta ${ }_{2}$-AR of rat myocardium and human myocardium, but provided that this efficiency is reduced artificially, for example lysophosphatidylcholine [7] or the pathological process [9,10]. This can be considered histidine as a kind of "chaperone", restoring the efficiency of signal transmission from adrenergic to intracellular effector, and points to the prospects of the using of histidine in clinical practice, as efficiency activation of myocardial beta - AP are $^{-}$ reduced in hypertension [12] and heart failure [13]. It is known that both of these kinds of diseases are found in pregnant women [14]. Therefore, question about the impact of histidine on contractility and myocardial adrenoreactivity at humans and animals, including at the presence of pregnancy, is of great interest. It should be noted that in the literature there is no information about influence of histidine on myocardial contractility and adrenoreactivity at pregnant animals and humans. Moreover, analysis of literature data indicates scarcity and contradictory information about the nature of the changes in the physiological properties of the myocardium during pregnancy $[15,16]$.

With all that said, the goal was set - in the experiments with strips of myocardium of the right ventricle of nonpregnant rats (including estrous cycle phase) and pregnant rats (for 5 - 20 days) rats to evaluate the effect of histidine $\left(10^{-10}-10^{-4} \mathrm{~g} / \mathrm{mL}\right.$ ) on its contractility and responses to adrenaline $\left(10^{-9}\right.$ and $\left.10^{-5} \mathrm{~g} / \mathrm{ml}\right)$ and investigate the effects of histidine $\left(10^{-4} \mathrm{~g} / \mathrm{mL}\right)$ on the contractile effects of adrenaline $\left(10^{-5} \mathrm{~g} / \mathrm{mL}\right)$ in the presence of a non-selective blocker of beta -AP propranolol, selective blocker of beta $_{1}$-AR atenolol and non-selective blocker of alpha-AP nicergoline.

\section{Research Methods and Techniques of Statistical Processing}

\section{Objects of research}

Studied 60 strips of myocardium of the right ventricle of rats, which length reached 8-13 mm, and width - 1-2 $\mathrm{mm}$. The extraction of heart occurred under ether anesthesia. Of these 8 rats were taken in experience in proestrus phase, 11 - in the 
estrus phase, 13 - in metaestrus phase, 8 - in the diestrus phase, 4 rats were taken on 5-9 days of pregnancy, 6 rats - on 12-14 days of pregnancy, and 10 rats on 16 -20 days of pregnancy. The phase of the estrous cycle was determined by vaginal smear pattern [17]. Gestation period was determined by weight and the length of the fetus [18].

\section{Method registration of contraction of rat myocardium}

The registration of contractions of myocardial strips were performed as described in [7]. To this strip was placed in the working chamber (volume $1 \mathrm{ml}$ ) of "Miotsitograph" (brand "Noris", Russia). It continuously perfused at $37{ }^{\circ} \mathrm{C}$ at a rate of $1.1 \mathrm{~mL} / \mathrm{min}$ oxygenated (100\% oxygen) Krebs solution using a syringe dispenser (brand "Noris"). Contractions of myocardial strips caused by single rectangular stimuli ( $5 \mathrm{~ms}, 20 \mathrm{~V}, 1$ $\mathrm{Hz}$ ) from the stimulator ESL-1. To register an isometric contraction applied force sensor (Honeywell, USA), whose signal through the analog-to-digital converter ADC-70 aircraft. ("Rudnev-Shilyaev", Russia) was applied to the computer. In each experiment the strip was stretched to an optimal length, at which it generated contractions of maximum force.

\section{Study design}

It was carried out eight (I-VIII) series of experiments (Tables 1,2, Figure 1). In series I (nonpregnant rats) and II (pregnant rats) containing 32 stages (Table 1) evaluated the effect of histidine at concentrations ranging from $10^{-10}$ to $10^{-4} \mathrm{~g} / \mathrm{mL}$ (sequentially, i.e. through washing with Krebs solution) on the force of the contraction, including on background adrenaline, used near the threshold concentration $\left(10^{-9} \mathrm{~g} / \mathrm{mL}\right)$, which allows to reveal a beta-adrenomodulatory action of the test substance.

Table 1: The force of the evoked contraction (in \% to the force, which observed on previous stage of the experiment, the median and 25 th and 75 th percentiles) of strips of the right ventricle myocardium of nonpregnant (estrogen or progesterone background, and as a whole) and pregnant women (5-20 day) rats at action of adrenaline ( $\left.10^{-9} \mathrm{~g} / \mathrm{mL}\right)$, histidine $\left(10^{-10}-10^{-4} \mathrm{~g} / \mathrm{mL}\right)$ or its mixture.

\begin{tabular}{|c|c|c|c|c|c|}
\hline \multirow{2}{*}{$\begin{array}{l}\text { Steps of } \\
\text { experience }\end{array}$} & \multirow{2}{*}{ Substance } & \multicolumn{3}{|c|}{$\begin{array}{l}\text { Nonpregnant rats } \\
\text { (series I, } n=10)\end{array}$} & \multirow{2}{*}{$\begin{array}{l}\text { Pregnant rats } \\
\text { (series } I 1, \mathrm{n}=10 \text { ) }\end{array}$} \\
\hline & & estrogenic background ( $n=5$ ) & $\begin{array}{l}\text { progesterone background } \\
\qquad(n=5)\end{array}$ & $\begin{array}{l}\text { regardless of the phase of the } \\
\text { cycle }\end{array}$ & \\
\hline 2 & $\begin{array}{l}\text { Adrenaline } \\
\left(10^{-9} \mathrm{~g} / \mathrm{mL}\right)\end{array}$ & $\begin{array}{c}101 \\
(100 ; 125)\end{array}$ & $\begin{array}{c}104 \\
(103 ; 115)^{\star}\end{array}$ & $\begin{array}{c}104 \\
(102 ; 115)\end{array}$ & $\begin{array}{c}99 \\
(92 ; 127)\end{array}$ \\
\hline 4 & $\begin{array}{c}\text { Histidine } \\
\left(10^{-10} \mathrm{~g} / \mathrm{mL}\right)\end{array}$ & $\begin{array}{c}99 \\
(97 ; 116)\end{array}$ & $\begin{array}{c}100 \\
(98 ; 122)\end{array}$ & $\begin{array}{c}99 \\
(97 ; 114)\end{array}$ & $\begin{array}{c}113 \\
A(105 ; 152) *\end{array}$ \\
\hline 6 & Histidine + adrenaline & $\begin{array}{c}91 \\
(87 ; 135)\end{array}$ & $\begin{array}{c}86 \\
(81 ; 133)\end{array}$ & $\begin{array}{c}89 \\
(82 ; 123)\end{array}$ & $\begin{array}{c}106 \\
(102 ; 116\end{array}$ \\
\hline 8 & $\begin{array}{l}\text { Histidine } \\
\left(10^{-9} \mathrm{~g} / \mathrm{mL}\right)\end{array}$ & $\begin{array}{c}94 \\
(93 ; 103)\end{array}$ & $\begin{array}{c}105 \\
(86 ; 119)\end{array}$ & $\begin{array}{c}97 \\
(86 ; 107)\end{array}$ & $\begin{array}{c}110 \\
(104 ; 126)^{\star \#}\end{array}$ \\
\hline 10 & Histidine + adrenaline & $\begin{array}{c}84^{\star} \\
(81 ; 97)\end{array}$ & $\begin{array}{c}86 \\
(85 ; 116)\end{array}$ & $\begin{array}{c}86 \\
(84 ; 104) A\end{array}$ & $\begin{array}{c}107 \\
(94 ; 131)^{\#}\end{array}$ \\
\hline 12 & $\begin{array}{l}\text { Histidine } \\
\left(10^{-8} \mathrm{~g} / \mathrm{mL}\right)\end{array}$ & $\begin{array}{c}100 \\
(94 ; 127)\end{array}$ & $\begin{array}{c}97 \\
(92 ; 161)\end{array}$ & $\begin{array}{c}99 \\
(91 ; 128)\end{array}$ & $\begin{array}{c}118 \\
(105 ; 151)^{\star}\end{array}$ \\
\hline 14 & Histidine + adrenaline & $\begin{array}{c}108 \\
(93 ; 113)\end{array}$ & $\begin{array}{c}93 \\
(83 ; 138)\end{array}$ & $\begin{array}{c}101 \\
(84 ; 112)\end{array}$ & $\begin{array}{c}121 \\
(102 ; 133)^{\star}\end{array}$ \\
\hline 16 & $\begin{array}{l}\text { Adrenaline } \\
\left(10^{-9} \mathrm{~g} / \mathrm{mL}\right)\end{array}$ & $\begin{array}{c}106 \\
(93 ; 120)\end{array}$ & $\begin{array}{c}101 \\
(100 ; 137)\end{array}$ & $\begin{array}{c}104 \\
(94 ; 118)\end{array}$ & $\begin{array}{c}112 \\
(105 ; 126)^{\star}\end{array}$ \\
\hline 18 & $\begin{array}{c}\text { Histidine } \\
\left(10^{-7} \mathrm{~g} / \mathrm{mL}\right)\end{array}$ & $\begin{array}{c}103 \\
(99 ; 124)\end{array}$ & $\begin{array}{c}101 \\
(92 ; 106)\end{array}$ & $\begin{array}{c}102 \\
(94 ; 115)\end{array}$ & $\begin{array}{c}115 \\
(105 ; 130)\end{array}$ \\
\hline 20 & Histidine + adrenaline & $\begin{array}{c}82 \\
(79 ; 121)\end{array}$ & $\begin{array}{c}90 \\
(81 ; 104)\end{array}$ & $\begin{array}{c}86 \\
(78 ; 112)\end{array}$ & $\begin{array}{c}89 \\
(87 ; 107)^{\star} A, \Gamma\end{array}$ \\
\hline 22 & $\begin{array}{c}\text { Histidine } \\
\left(10^{-6} \mathrm{~g} / \mathrm{mL}\right)\end{array}$ & $\begin{array}{c}75 \\
(71 ; 135) \\
\end{array}$ & $\begin{array}{c}110 \\
(109 ; 125)\end{array}$ & $\begin{array}{c}109 \\
(72 ; 124)\end{array}$ & $\begin{array}{c}115 \\
(107 ; 125)^{\star}\end{array}$ \\
\hline 24 & Histidine + adrenaline & $\begin{array}{c}80 \\
(79 ; 114)\end{array}$ & $\begin{array}{c}98 \\
(89 ; 107)\end{array}$ & $\begin{array}{c}91 \\
(80 ; 106)\end{array}$ & $\begin{array}{c}100 \\
(93 ; 108) A, \Gamma\end{array}$ \\
\hline 26 & $\begin{array}{c}\text { Histidine } \\
\left(10^{-5} \mathrm{~g} / \mathrm{mL}\right)\end{array}$ & $\begin{array}{c}90 \\
(79 ; 152)\end{array}$ & $\begin{array}{c}119 \\
(87 ; 132)\end{array}$ & $\begin{array}{c}104 \\
(76 ; 134)\end{array}$ & $119(119 ; 165)^{*}$ \\
\hline 28 & Histidine + adrenaline & $\begin{array}{c}80 \\
(74 ; 147)\end{array}$ & $\begin{array}{c}99 \\
(86 ; 128)\end{array}$ & $\begin{array}{c}91 \\
(77 ; 138)\end{array}$ & $\begin{array}{c}97 \\
(85 ; 107) A, \Gamma\end{array}$ \\
\hline 30 & $\begin{array}{l}\text { Histidine } \\
\left(10^{-4} \mathrm{~g} / \mathrm{mL}\right.\end{array}$ & $\begin{array}{c}87 \\
(82 ; 145)\end{array}$ & $\begin{array}{c}117 \\
(96 ; 120)\end{array}$ & $\begin{array}{c}103 \\
(84 ; 120)\end{array}$ & $\begin{array}{c}130 \\
(114 ; 148)^{\star}\end{array}$ \\
\hline 32 & Histidine + adrenaline & $\begin{array}{c}83 \\
(83 ; 122)\end{array}$ & $\begin{array}{c}80 \\
(74 ; 114)\end{array}$ & $\begin{array}{c}83 \\
(75 ; 114)\end{array}$ & $\begin{array}{c}125 \\
(93 ; 150)\end{array}$ \\
\hline
\end{tabular}

Note: * - difference with the previous step (Krebs solution) was significantly $\left(\mathrm{p}<0.05^{\mathrm{w}}\right)$; \# - difference with nonpregnant statistically significant ( $\left.\mathrm{p}<0.05 \mathrm{M}-\mathrm{w}\right)$; A and $\mathrm{H}-$ difference with the effect of adrenaline $(A)$ or histidine $(H)$ was significantly $\left(p<0.05^{\mathrm{M}-\mathrm{W}}\right)$. Steps $1,3,5,7,9,11,13,15,17,19,21,23,25,27,29,31-$ strips perfusion with Krebs solution. 
Table 2: Force of induced contractions (in \% to the indicated phase of the experiment, the median and 25th and 75th percentiles) of myocardial strips of the right ventricle of nonpregnant rats (estrogenic background, progesterone background and as a whole) and of pregnant (5-20 days) rats before and at expose adrenergic agents.

\begin{tabular}{|c|c|c|c|c|}
\hline \multirow{2}{*}{$\begin{array}{l}\text { The experimental conditions and units of } \\
\text { forces of evoked contraction }\end{array}$} & \multicolumn{3}{|c|}{ Nonpregnant rats } & \multirow{2}{*}{$\begin{array}{l}\text { Pregnant rats } \\
\qquad(\mathrm{n}=10)\end{array}$} \\
\hline & estrogenic background $(n=5)$ & $\begin{array}{l}\text { progesterone background } \\
\qquad(n=5)\end{array}$ & $\begin{array}{l}\text { regardless of the phase of the } \\
\text { cycle }(n=10)\end{array}$ & \\
\hline \multicolumn{5}{|c|}{ Adrenaline, $10^{-5} \mathrm{~g} / \mathrm{mL}$, series III (nonpregnant rats) and series IV (pregnant rats) } \\
\hline 1st testing, in \% to step $1(\mathrm{KS})$ & $121(117 ; 160)^{*}$ & $108(104 ; 143)$ & $119(111 ; 142)^{*}$ & $121(113 ; 126)^{\star}$ \\
\hline 2nd testing, in \% to step $7(\mathrm{KS})$ & $137(126 ; 156)^{\star}$ & $127(118 ; 145)^{*}$ & $128(1119 ; 144)^{\star}$ & $119(99 ; 143) \#$ \\
\hline \multicolumn{5}{|c|}{ Adrenaline, $10^{-5} \mathrm{~g} / \mathrm{mL}$, series $\mathrm{VI}$ (nonpregnant rats) and series $\mathrm{VI}$ (pregnant rats) } \\
\hline 1st testing, in \% to step $1(\mathrm{KS})$ & $120(118 ; 191)^{\star}$ & $110(107 ; 121)^{\star}$ & $117(109 ; 124)^{*}$ & $116(107 ; 129)$ \\
\hline 2nd testing, in \% to step $7(\mathrm{KS})$ & $104(103 ; 84)$ & $108(107 ; 144)$ & $108(106 ; 113)$ & $118(111 ; 155)^{\star}$ \\
\hline \multicolumn{5}{|c|}{ Propranol $10^{-8} \mathrm{~g} / \mathrm{mL}$, series III and IV } \\
\hline In \% to step 3(KS) & $98(94 ; 137)$ & $87(86 ; 94) \star \ni$ & $92(89 ; 101)$ & $105(99 ; 117) \#$ \\
\hline \multicolumn{5}{|c|}{ Adrenaline, $10^{-5} \mathrm{~g} / \mathrm{mL}+$ propranol $10^{-8} \mathrm{~g} / \mathrm{mL}$, series III and IV } \\
\hline In \% to step 4 (Pr8) & $65(63 ; 80)^{\star}$ & $71(70 ; 92)^{\star}$ & $70(65 ; 85)^{\star}$ & $82(76 ; 100)^{\star}$ \\
\hline \multicolumn{5}{|c|}{ Adrenaline, $10^{-5} \mathrm{~g} / \mathrm{mL}+$ propranol $10^{-8} \mathrm{~g} / \mathrm{mL}+$ histidine, $10^{-4} \mathrm{~g} / \mathrm{mL}$, series III and IV } \\
\hline In \% to step 4 (Pr8) & $95(91 ; 118)$ & $97(87 ; 104)$ & $96(87 ; 103)$ & $91(77-110)$ \\
\hline \multicolumn{5}{|c|}{ Atenolol, $10^{-6} \mathrm{~g} / \mathrm{mL}$ (series V) и $10^{-8} \mathrm{~g} / \mathrm{m}$ (серия VI) } \\
\hline In \% to step 3(KS) & $74(59 ; 95)^{\star}$ & $94(84 ; 109)$ & $86(76 ; 101)$ & $110(94 ; 135) \#$ \\
\hline \multicolumn{5}{|c|}{ Adrenaline, $10^{-5} \mathrm{~g} / \mathrm{mL}+$ atenolol, $10^{-8} \mathrm{~g} / \mathrm{mL}$, series $\mathrm{V}$ and $\mathrm{VI}$} \\
\hline In \% to step 4 (At) & $93(77 ; 107)$ & $85(80 ; 89)^{\star}$ & $85(75 ; 99)^{\star}$ & $76(66 ; 98)^{\star}$ \\
\hline \multicolumn{5}{|c|}{ Adrenaline, $10^{-5} \mathrm{~g} / \mathrm{mL}+$ atenolol, $10^{-8} \mathrm{~g} / \mathrm{mL}+$ histidine, $10^{-4} \mathrm{~g} / \mathrm{mL}$, series $\mathrm{V}$ and $\mathrm{VI}$} \\
\hline In \% to step 4 (At) & $106(105 ; 137)^{\star}$ & $87(84 ; 94) * \ni$ & $98(87 ; 107)$ & $105(90 ; 142)$ \\
\hline \multicolumn{5}{|c|}{ Adrenaline, $10^{-5} \mathrm{~g} / \mathrm{mL}$ series VII (nonpregnant rats ) } \\
\hline 1 st testing, in \% to step $1(\mathrm{KS})$ & $123(119 ; 146)^{*}$ & $150(123 ; 191)$ & $126(116 ; 170)^{*}$ & not investigated \\
\hline 2nd testing, in \% to step $7(\mathrm{KS})$ & $127(122 ; 97)^{\star}$ & $137(124 ; 142)^{\star}$ & $128(119 ; 138)^{*}$ & not investigated \\
\hline \multicolumn{5}{|c|}{ Nicergoline, $10^{-8} \mathrm{~g} / \mathrm{mL}$ series VII $(\mathrm{n}=10)$} \\
\hline In \% to step 3(KS) & $100(92 ; 108)$ & $93(84 ; 110)$ & $97(85 ; 108)$ & not investigated \\
\hline \multicolumn{5}{|c|}{ Adrenaline, $10^{-5} \mathrm{~g} / \mathrm{mL}+$ nicergoline, $10^{-8} \mathrm{~g} / \mathrm{mL}$, series VII } \\
\hline In \% to step 4 (Pr8) & $89(87 ; 103)$ & $77(76 ; 110)$ & $88(77 ; 104)$ & not investigated \\
\hline \multicolumn{5}{|c|}{ Adrenaline, $10^{-5} \mathrm{~g} / \mathrm{mL}+$ nicergoline, $10^{-8} \mathrm{~g} / \mathrm{mL}+$ histidine, $10^{-4} \mathrm{~g} / \mathrm{mL}$, series VII } \\
\hline In \% to step 4 (Pr8) & $124(115 ; 128)$ & $113(109 ; 122)^{\star}$ & $114(110 ; 125)^{*}$ & not investigated \\
\hline \multicolumn{5}{|c|}{ Nicergoline, $10^{-8} \mathrm{~g} / \mathrm{mL}+$ propranolol, $10^{-8} \mathrm{~g} / \mathrm{mL}$, series VIII $(\mathrm{n}=8)$} \\
\hline In \% to step 1(KS) & not investigated & not investigated & $102(88 ; 128)$ & not investigated \\
\hline \multicolumn{5}{|c|}{ Adrenaline, $10^{-5} \mathrm{~g} / \mathrm{mL}+$ nicergoline, $10^{-8} \mathrm{~g} / \mathrm{mL}+$ propranolol $10^{-8} \mathrm{~g} / \mathrm{mL}$, series VIII $(\mathrm{n}=8)$} \\
\hline In \% to step $3(\mathrm{~N} 8+\mathrm{Pr} 8)$ & not investigated & not investigated & $90(82 ; 101)$ & not investigated \\
\hline \multicolumn{5}{|c|}{ Adrenaline, $10^{-5} \mathrm{~g} / \mathrm{mL}+$ nicergoline, $10^{-8} \mathrm{~g} / \mathrm{mL}+$ propranolol $10^{-8} \mathrm{~g} / \mathrm{mL}+$ histidine, $10^{-4} \mathrm{~g} / \mathrm{mL}$, series VIII } \\
\hline In \% to step $3(\mathrm{~N} 8+\mathrm{Pr} 8)$ & not investigated & not investigated & $103(88 ; 127)$ & not investigated \\
\hline
\end{tabular}

Note: * - difference with indicated step statistically significant $\left(\mathrm{p}<0.05^{\mathrm{W}}\right)$; \# - difference with nonpregnant rats statistically significant $\left(\mathrm{p}<0.05^{\mathrm{M}-\mathrm{w})}\right.$; $\mathrm{E}$ - difference with estrogen background statistically significant $\left(\mathrm{p}<0.05^{\mathrm{M}-\mathrm{w}}\right)$. KS - Krebs solution; Pr8- propranolol, $10^{-8} \mathrm{~g} / \mathrm{mL}$; At - atenolol; $10^{-8} \mathrm{or} 10^{-6} \mathrm{~g} / \mathrm{mL}, \mathrm{H} 8-\mathrm{nicergoline}, 10^{-8} \mathrm{~g} / \mathrm{mL}$.

In series III and V (nonpregnant rats), IV and VI (pregnant rats) and VII (nonpregnant rats) consisting of eight stages (Table 2, Figure 1, panel A, B and C), the effect of histidine $\left(10^{-4} \mathrm{~g} / \mathrm{mL}\right)$ on the effect of adrenaline in the above-threshold concentration $\left(10^{-5} \mathrm{~g} /\right.$ $\mathrm{mL})$ on the background of blocker of beta -AR propranolol $\left(10^{-8} \mathrm{~g} / \mathrm{mL}\right.$, series III and IV) or atenolol $\left(10^{-6} \mathrm{~g} / \mathrm{mL}\right.$ in series $\mathrm{V}$ and $10-8 \mathrm{~g} / \mathrm{mL}$ in series $\left.\mathrm{VI}\right)$, as well as nicergoline $\left(10^{-8} \mathrm{~g} / \mathrm{mL}\right.$, series VII $)$ or nicergoline $\left(10^{-8} \mathrm{~g} / \mathrm{ml}\right)$ together with propranolol $\left(10^{-8} \mathrm{~g} /\right.$ $\mathrm{mL}$; series VIII). This series (Figure 1, panel D) was carried out on the same strips of myocardium that series VII. It consisted of 5 stages (Table 2, Figure 1, panel D).

Force of contraction of myocardial strips expressed in $\mathrm{mN}$, or in $\mathrm{mN}$ per mg wet weight of the strip or in $\mathrm{mN}$ per mg dry weight, either expressed as a percentage of force of contraction, which is observed in the previous stage of the experiments, as indicated in the text and tables. The damp, or wet weight of strips (i.e. after removal of moisture with filter paper) and dry weight of strips (after 12 hour drying at room temperature) was determined with torsion balance type WT.

The substances used. We used L-histidine (SIGMA-ALDRICH, Japan), adrenaline hydrochloride (Moscow Endocrine Plant), propranolol (anaprelin, "Uralbiopharm", Russia), atenolol ("Synthesis", Russia), and nicergoline ("Obolenskoe", Russia). Krebs solution $(\mathrm{pH}=7.4)$ contained $(\mathrm{mM}): \mathrm{NaCl}-136 ; \mathrm{KCl}-4.7 ; \mathrm{CaCl}_{2}-2.52 ; \mathrm{MgCl}_{2}-1.2$; $\mathrm{KH}_{2} \mathrm{PO}_{4}-0.6 ; \mathrm{NaHCO}_{3}-4.7 ; \mathrm{C}_{6} \mathrm{H}_{12} \mathrm{O}_{6}-11$. 
A Series III

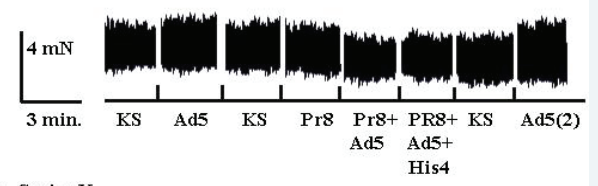

B Series $\mathrm{V}$
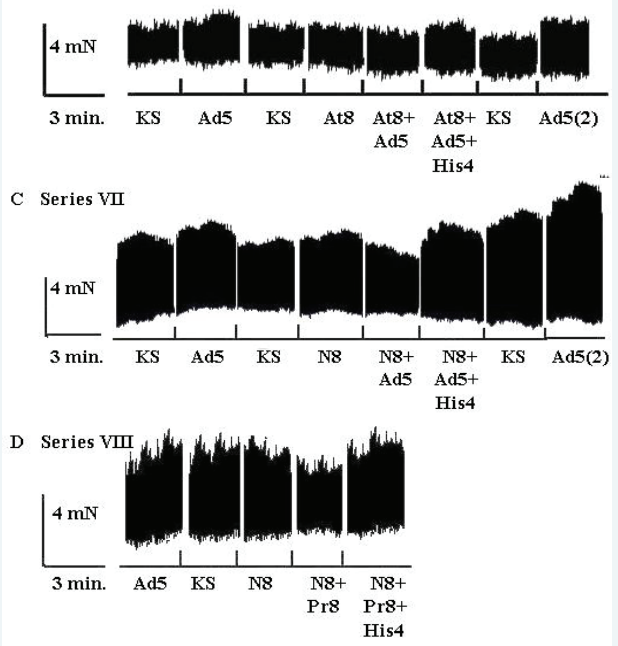

Figure 1: Mechanogramms - caused by electrostimulation $(1 \mathrm{~Hz}, 5 \mathrm{~ms}, 20 \mathrm{~V})$ contractions of myocardial strips of right ventricle of nonpregnant rats (Phase metaestrus; panels $A, C$ and $D$ ) and pregnant rat (17 day; panel $B)$ in steps 1-8 of series III (panel A), of series V (panel B), of series VII (panel C) and in steps 1-4 series VIII (panel D). Mechanograms demonstrate the ability of histidine $\left(10^{-4} \mathrm{~g} / \mathrm{mL}\right.$, His 4$)$ to restore the effectiveness of the activation of beta-adrenoceptors (AR), which reduced by propranolol $\left(10^{-8} \mathrm{~g} / \mathrm{mL}\right.$, Pr8; panel A), or by atenolol $\left(10^{-8} \mathrm{~g} / \mathrm{mL}\right.$, At8; panel B) or by nicergoline $\left(10^{-8} \mathrm{~g} / \mathrm{mL}\right.$, N8; panel C), and the absence of histidine effect against the backdrop of the joint effects of nicergoline $\left(10^{-8} \mathrm{~g} / \mathrm{mL}\right)$, and propranolol $\left(10^{-8} \mathrm{~g} / \mathrm{mL}\right.$, panel D). KS - Krebs solution; Ad5 - adrenaline, $10^{-5} \mathrm{~g} / \mathrm{mL}$; calibration - $4 \mathrm{mN}, 3 \mathrm{~min}$.

\section{Statistical analysis of the study results}

Statistical results of the study treatment was carried out using BioStat2009 Professional program. 5.8.4. (Analyst Firm Soft). The hypothesis of normality of distribution was assessed by the Shapiro-Wilk test. In the absence of normal distribution of parameters and given the small sample size, the results of the study, according to [19], presented in the text and tables as median and interquartile amplitude (25th and 75th percentiles). Assessment of the differences between two dependent samples (i.e. between steps of series) was performed using the paired Wilcoxon T test, and between independent samples (between series) - using the Mann-Whitney test $\mathrm{U}^{(\mathrm{M}-\mathrm{W})}$. In all cases the differences were considered statistically significant at $p<0.05$ [19], which means text and tables with simbol * (the difference with the previous stage of the experiment) or the \# (difference from baseline).

\section{Results of the Study}

\section{Mass of myocardial strips}

It was found that wet and dry weight of the strips of rat right ventricle whose value needed for contractility evaluation is independent of the phase of the cycle and the presence of pregnancy. Thus, for estrus and proestrus phase $(n=15)$, i.e. with the dominance of estrogen $[20]$ "wet" mass was $88(75 ; 116) \mathrm{mg}$ and the "dry" mass was 20 $(18,26) \mathrm{mg}$. For metaestrus and diestrus phase $(\mathrm{n}=15)$, i.e. progesterone dominance these values were respectively $100(84 ; 130)$ and $22 \mathrm{mg}(20 ; 30) \mathrm{mg}$ (difference from rats in proestrus and estrus phase, not statistically significant, $\left.p>0.05^{\mathrm{M}-\mathrm{w}}\right)$. The average non-pregnant rats (without phase of the cycle, $n=30$ ) wet mass of strips was $88(72$; 103) $\mathrm{mg}$, and dry mass was $22(20 ; 35) \mathrm{mg}$. The same value had myocardial strips from 
pregnant rats at $5-20$ days of gestation $(n=20)$, respectively $86(70 ; 124) \mathrm{mg}$ and 21 $(18 ; 28) \mathrm{mg}\left(\mathrm{p}>0.05^{\mathrm{M}-\mathrm{w}}\right)$. Hence the method of preparation of myocardial strips was the same in different series. This allows you to compare myocardium contractility of nonpregnant and pregnant rats.

\section{Myocardial contractility (based on series I-VI)}

Judging from the results of a series I-VI, contractility of myocardium of rat right ventricle, estimated by the force caused by contractions (in $\mathrm{mN}$, in $\mathrm{mN}$ per mg wet mass or $\mathrm{mN}$ per mg dry mass of strips) in step 1, i.e. before any effects are not dependent on the phase of the estrus cycle and the presence of pregnancy. Thus, when estrogen dominance $(\mathrm{n}=15)$, it was $3.4(2.0 ; 4.6) \mathrm{mN}$ or $0.03(0.02 ; 0.04) \mathrm{mN} / \mathrm{mg}$ of wet weight of the strips or $0.12(0.08 ; 0.18) \mathrm{mN} / \mathrm{mg}$ of dry weight of the strips $(\mathrm{n}=30)$, and with the dominance of progesterone $(n=15)$ respectively $2.5(2.2 ; 4.0) \mathrm{mN}$ or $0.03(0.02$; $0.04) \mathrm{mN} / \mathrm{mg}$ of wet weight, and $0.11(0.07 ; 0.15) \mathrm{mN}$ per mg of dry weight $(\mathrm{n}=30)$; while the differences were not statistically significant ( $p>0.05^{\mathrm{M}-\mathrm{w}}$ ). So we thought it possible to assess the force of myocardial contractions of nonpregnant rats excluding cycle phase. In this case, the force of contraction was $2.8(2.0,3.1) \mathrm{mN}$ or $0.03(0.02$; $0.04) \mathrm{mN} / \mathrm{mg}$ of wet weight, or $0.12(0.08 ; 0.15) \mathrm{mN} / \mathrm{mg}$ of dry weight. In pregnant rats, it was the same as in nonpregnant rats $\left(\mathrm{p}>0.05^{\mathrm{M}-\mathrm{w}}\right)$, and amounted to 2.8 (2.2; 4.1) $\mathrm{mN}$ or $0.02(0.02 ; 0.04) \mathrm{mN}$ per $\mathrm{mg}$ of wet weight, or $0.13(0.08 ; 0.2) \mathrm{mN}$ per $\mathrm{mg}$ of dry weight. The absence of differences of contraction force of myocardium between nonpregnant and pregnant rats allowed to compare the results between a series of studies that have evaluated the effect of substances on the contractility of the strips of rat right ventrile given the presence of pregnancy.

A. The results of the series I and II: Each test in a series o I and II included 32 step (the duration of each - 3 min.). They are carried out according to the scheme (Table 1): Krebs solution (KS) $\rightarrow$ adrenaline, $10^{-9} \mathrm{~g} / \mathrm{mL}\left(\right.$ Ad 9) $\rightarrow \mathrm{KS} \rightarrow$ histidine $\left(10^{-10} \mathrm{~g} /\right.$ $\mathrm{mL}, \mathrm{His} 10) \rightarrow \mathrm{KS} \rightarrow \mathrm{His} 10+\mathrm{Ad} 9 \rightarrow \mathrm{KS} \rightarrow \mathrm{His} 9 \rightarrow \mathrm{KS} \rightarrow \mathrm{His} 9+\mathrm{Ad} 9 \rightarrow \mathrm{KS} \rightarrow \ldots$. Ad 9 (step16) $\rightarrow \mathrm{KS} \rightarrow$ His $7 \rightarrow$ His $7+$ Ad 9.... $\rightarrow \mathrm{KS} . \rightarrow$ His $4 \rightarrow \mathrm{KS} \rightarrow$ His $4+$ Ad 9. It is possible to assess the initial adrenoreactivity of myocardium, as well as the effect of histidine on contractility and adrenoreactivity of myocardial, including ability of histidine to exercise the beta adrenosensibilizatory activity. Consider the results of these two series, separately in respect of effects of adrenaline, histidine, and its mixtures.

Effect of low concentration of adrenaline $\left(10^{-9} \mathrm{~g} / \mathrm{mL}\right)$ : In order to avoid reducing of the effectiveness of adrenaline during prolonged exposure experiment testing strips with adrenaline $\left(10^{-9} \mathrm{~g} / \mathrm{mL}\right)$ was performed twice (Table 1$)$ - at the beginning of experiments (stage 2) and in the middle (step 16). In experiments with nonpregnant rats have shown (Table 1), that adrenaline, as a rule, does not change the force pf contractions - ai rats with the dominance of estrogen force of contraction during the 1 st and 2 nd tests was respectively $101 \%$ and $106 \%$ of the background, at rats with the dominance of progesterone - respectively 104\%* and 101\% (with estrogen background differences were not statistically significant), but in general, i.e. excluding phases $104 \%$ and $104 \%$. In pregnant rats adrenaline at 1st test did not change of contraction force (it was 99\%), while at the 2nd test is a statistical significantly increased its up to $112 \% *$ of the background. At the same time all the difference with the nonpregnant rats were not statistically significant. Consequently, the investigated concentration of adrenaline $\left(10^{-9} \mathrm{~g} / \mathrm{mL}\right)$ or no effect on the contraction force of nonpregnant and pregnant rats, or slightly increases it. This means that the investigated concentration of adrenaline $\left(10^{-9} \mathrm{~g} / \mathrm{mL}\right)$ is subthreshold or close to the threshold, i.e. near the threshold. Using of this concentration implements one of the conditions necessary for the detection of beta-adrenosensibilizatory activity of substances, including histidine. You can also state that during pregnancy adrenoreactivity of myocardium, judging by the reaction to the adrenaline in a concentration of $10^{-9} \mathrm{~g} / \mathrm{mL}$, not increases. 
Influence of histidine $\left(10^{-10}, 10^{-9}, . ., 10^{-4} \mathrm{~g} / \mathrm{mL}\right)$ on the force of evoked myocardial contraction: It was found (Table. 1, Steps 4, 8, 12, 18, 22, 26 and 30), that in nonpregnant rats (regardless of the phase of the cycle) histidine in any of the studied concentrations did not significantly alter of the force of myocardial contraction. At the same time, the effect of histidine when used in relatively high concentrations $\left(10^{-6}, 10^{-5}\right.$ and $\left.10^{-4} \mathrm{~g} / \mathrm{mL}\right)$, to some extent dependent on the phase of the cycle histidine increase contraction force at rat with progesterone dominance. For example, histidine at a concentration of $10^{-6} \mathrm{~g} / \mathrm{mL}$ in rats with estrogen background reductions of contraction force up 75\% from the previous step, and in rats with progesterone background increase of force up $110 \%$. For histidine at a concentration of $10^{-5} \mathrm{~g} / \mathrm{mL}$ these values were respectively $90 \%$ and $119 \%$, and for histidine at a concentration of $10^{-4} \mathrm{~g} / \mathrm{mL}$ - respectively $87 \%$ and $117 \%$. (Table 1 ). However, all these changes were not statistically significant.

Unlike the nonpregnant rat histidine in pregnant rats in all tested concentrations significantly increased the force of contraction (up to $110 \%-130 \%$ of the background level) and only in the experiments with histidine at a concentration of $10^{-7} \mathrm{~g} / \mathrm{mL}$ this increase (up to $115 \%$ ) was not statistically significant. At the same time a statistically significant difference from the nonpregnant rats were detected only for histidine at a concentration of $10^{-9} \mathrm{~g} / \mathrm{mL}(110 \%$ vs. $97 \%)$. Note that the degree of increasing of contraction force of myocardium at pregnant rats under the influence of histidine did not depend on its concentration in the medium (Table 1). Thus, histidine does not effect on myocardial contractility at nonpregnant rats (although it tends to increase when progesterone dominance), but it increases myocardial contractility at pregnant rats (although the degree of increasing does not depend on the concentration of histidine.

Influence of hystidine $\left(10^{-10}, 10^{-9}, . ., 10^{-4} \mathrm{~g} / \mathrm{mL}\right)$ to the effect of adrenaline used in the near-threshold concentration $\left(\mathbf{1 0}^{-9} \mathbf{g} / \mathbf{m L}\right)$ : Established (Table 1, steps 6, 10, $14,20,24,28$ and 32$)$ that histidine $\left(10^{-10}-10^{-4} \mathrm{~g} / \mathrm{mL}\right)$ did not increase the ability of adrenaline to show positive inotropic effects in experiments with myocardium of nonpregnant rats (regardless of the cycle phase) and pregnant rats. Moreover, histidine at concentrations $10^{-7}, 10^{-6}$ and $10^{-5} \mathrm{~g} / \mathrm{mL}$ in experiments with pregnant rat myocardium it significantly reduced the ability of adrenaline to increase the force of contractions. For example, in experiments with pregnant rats in the study of the histidine at a concentration of $10^{-5} \mathrm{~g} / \mathrm{ml}$ the force of contractions on the background of adrenaline (stage 16) was $112 \%$ * from the previous stage, against histidine $-119 \%$ *, and against the backdrop of a mixture of "histidine + adrenaline "- 97\%. All this means that histidine $\left(10^{-10}-10^{-4} \mathrm{~g} / \mathrm{mL}\right)$ in the experiments with intact myocardium does not exhibit beta-adrenosensibilizatory activity, and in some cases $\left(10^{-7}, 10^{-6}\right.$ and $10^{-5} \mathrm{~g} /$ $\mathrm{mL}$ ), even shows beta-adrenoblocking activity.

B. The results of series III-VI: This series consisted of eight stages (Figure 1, panels A-C). They are carried out under the scheme: the Krebs solution (KS) $\rightarrow$ adrenaline, $10^{-5}$ $\mathrm{g} / \mathrm{mL}(\mathrm{Ad} 5) \rightarrow \mathrm{KS} \rightarrow$ blocker of adrenoceptors(AR) $\rightarrow$ blocker of AR + Ad5 $\rightarrow$ blocker $\mathrm{AR}+\mathrm{Ad} 5+$ histidine, $10^{-4} \mathrm{~g} / \mathrm{mL} \rightarrow \mathrm{KS} \rightarrow \mathrm{Ad} 5$. Consider the results separately for the effects of adrenaline, blockers and histidine.

The effect of adrenaline $\left(\mathbf{1 0}^{-5} \mathbf{g} / \mathbf{~ m L}\right)$ : Established (Table 2, Figures 1,2). That the concentration of adrenaline $10^{-5} \mathrm{~g} / \mathrm{mL}$ at the 1 st test, i.e. before exposure blocker and histidine, as well as the 2nd test, i.e. on the eighth (final) stage of the series, as a rule, significantly increases the force of contraction, i.e. induce a positive inotropic effect. However, its expression does not depend on the stage of the reproductive process. Thus, in the series III and IV (study of the effect of propranolol) in rats with estrogen background adrenaline at first test increased force of contraction up to $121 \%$ from the previous phase, at rats with progesterone background adrenaline increased force of contraction up to $108 \%$ (the differences between the backgrounds are insignificant; 


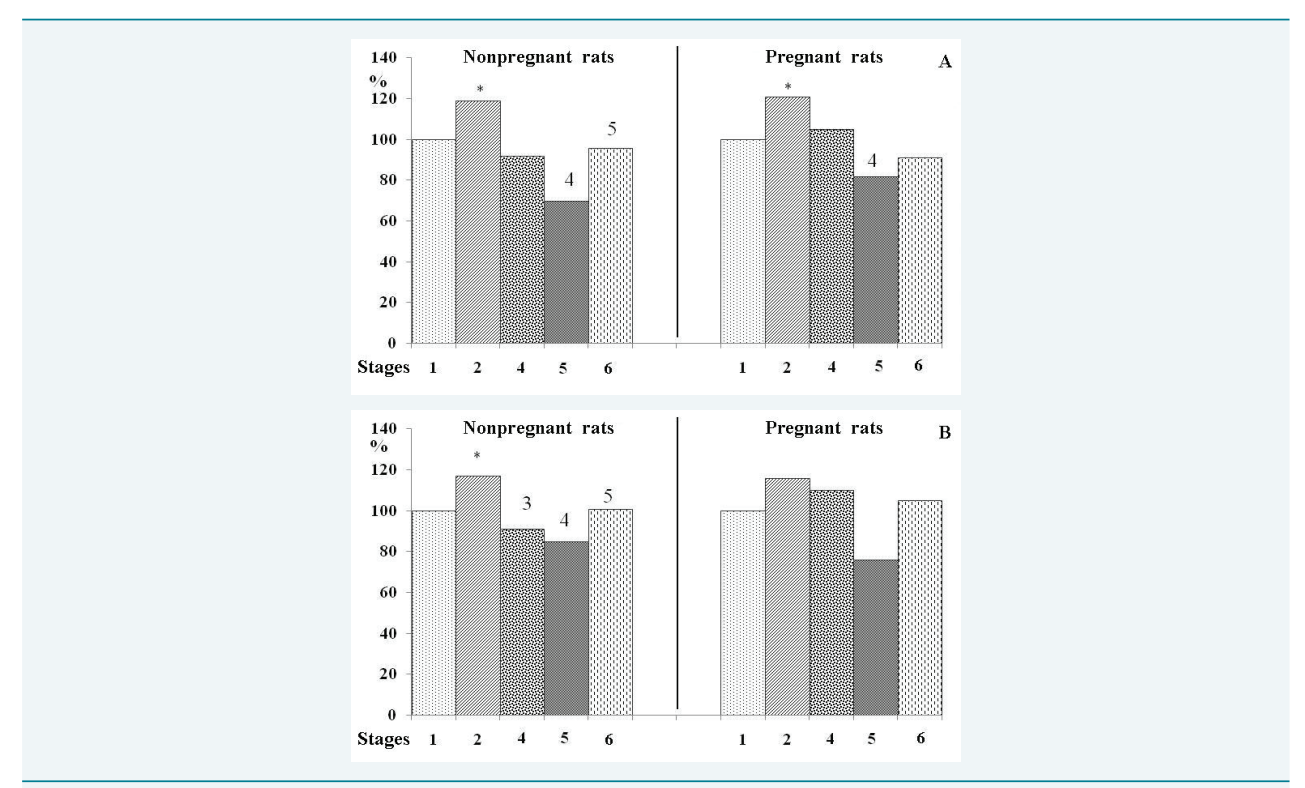

Figure 2: Force (median) of evoked by electrostimulation of contractions of the myocafrdial strips of right ventricle of nonpregnant and pregnant (5-20 day) rats in experiments with blockers of beta-adrenoceptors propranolol $\left(10^{-8} \mathrm{~g} / \mathrm{mL}\right.$; panel A) and atenolol $\left(10^{-8} \mathrm{~g} / \mathrm{mL}\right.$ or $10^{-6} \mathrm{~g} / \mathrm{mL}$; panel B) in a series with histidine $\left(10^{-4} \mathrm{~g} / \mathrm{mL}\right)$ and adrenaline $\left(10^{-5} \mathrm{~g} / \mathrm{mL}\right)$

Note: stage 1 - perfusion with Krebs solution (force of contraction is taken as 100\%); stage 2- effects of adrenaline ( force in \% of stage 1 ); stage 4 - impacts blocker (force in \%\% to the previous stage, i.e, force at perfusing with Krebs solution); stage 5 - effects of adrenaline on the background of blocker (in \% to force at stage 4); stage 6 - effects of adrenaline on the background blocker and histidine (in \% to force at stage 4 ). * - differences with comparison stage is statistically significant at Wilcoxon test $(p<0.05) ; 3,4,5$ - the difference with the appropriate stage is statistically significant for Wilcoxon test $(p<0.05)$.

$p>0,05^{\mathrm{M}-\mathrm{w}} \mathrm{J}$, and as a whole, i.e. regardless of the phase of the cycle adrenaline increased force of contraction up to $119 \% *$ and in pregnant rats adrenaline increased force of contraction up to $121 \% *$ (differences with nonpregnant rats is insignificant, $\mathrm{p}>0.05$ M-W). Similarly, in experiments with atenolol with nonpregnat rats (series V) or with pregnant rats (series VI), these values at $1_{\text {ST }}$ test were $120 \% *$ and $110 \% *$ (differences between phones insignificant, $\mathrm{p}>0.05 \mathrm{M}-\mathrm{u})$, and at $2^{\text {nd }}$ test respectively $117 \% *$ and $116 \%$ (differences between pregnant and nonpregnant rats were not statistically significant, $p>0.05^{\mathrm{M}-\mathrm{w})}$. Thus, these results suggest that beta- adrenoreactivity of myocardium of rat right ventricle, which determined by the expression of inotropic effect of adrenaline in above-threshold concentration $\left(10^{-5} \mathrm{~g} / \mathrm{mL}\right)$ is independent of the phase of the estrous cycle, and of availability of pregnancy.

Influence of propranolol $\left(10^{-8} \mathrm{~g} / \mathrm{ml}\right)$ on contractility of rat myocardium: In the series III and series IV was (Table 2; Figure 1, panel A; Figure 2, panel A) was found that propranolol in experiments with myocardium of nonpregnant rats (with the dominance of estrogen background) is not influenced on the force of contractions (it was $98 \%$ from the previous step), in experiments with myocardium of rats with the dominance of progesterone background propranolol reduced it (up to 87\%*, while differences with estrogen background were statistically significant, $\mathrm{p}<0.05^{\mathrm{M}-\mathrm{w}}$ ), but propranololo did not alter the force of contraction in pregnant rats (it amounted to 105\%). This means that by itself propranolol may exhibit negative inotropic effect, which is typical, however, only for nonpregnant rats with the domination of progesterone background.

The effect of adrenaline $\left(10^{-5} \mathrm{~g} / \mathrm{ml}\right)$ against propranolol $\left(10^{-8} \mathrm{~g} / \mathrm{ml}\right)$ : Established (Table 2, Figure 1, panel A; Figure 2, panel A), which, independently from the stage of the reproductive process adrenaline on background of propranolol instead of a positive inotropic effect is statistically significant $(\mathrm{p}<0.05)$ exerts a negative effect, i.e. adrenaline reduces the force of contraction, including the estrogen background adrenalin reduces the force of myocardial contraction to $65 \% *$ from the previous stage, when progesterone 
background adrenalin reduces it to $71 \%$ *, in general, at nonpregnant rats adrenaline reduce reduces the force of contraction to $70 \% *$, and in pregnant rats to $82 \%$ * (all differences between group was not statistically significant, $p>0.05$ ).

Effect of adrenaline $\left(10^{-5} \mathrm{~g} / \mathrm{mL}\right)$ against propranolol $\left(10^{-8} \mathrm{~g} / \mathrm{mL}\right)$ and histidine $\left(\mathbf{1 0}^{-4} \mathbf{g} / \mathbf{m L}\right)$ : Established (Table 2, Figure 1, panel A; Figure 2, panel A), that independently from the stage of the reproductive process adding histidine $(10$ ${ }^{4} \mathrm{~g} / \mathrm{mL}$ ). stops negative inotropic effects of adrenaline, but it does not restore the ability of adrenaline to show positive inotropic effect. Indeed, the presence of histidine, propranolol and adrenaline force of contraction in rats with estrogen background was $95 \%$ of the level observed under the action of propranolol, with progesterone background - 97\%, in general, in nonpregnant rats was $96 \%$, and in pregnant - 91\% ( difference to baseline, and all differences between groups were not statistically significant, $\mathrm{p}>0.05$ ).

The effect of atenolol $\left(1^{-6}\right.$ and $\left.10^{-8} \mathbf{g} / \mathbf{m L}\right)$ : In series $\mathrm{V}$ is set (Table 2, Figure 1, panel B; Figure2, panel B), that atenolol at a concentration of $10^{-6} \mathrm{~g} / \mathrm{mL}$ in rats with the dominance of estrogen reduced force of contractiomn to $74 \%$ from the previous stage,in $\mathrm{n}$ rats with the dominance of progesterone atenolol had no effect on force of contractions (it was 94\%) and differences with estrogen background were not statistically significant, $\mathrm{p}>0.05^{(\mathrm{M}-\mathrm{W})}$, and in pregnant rats (series VI) atenolol used in a concentration of $10^{-8} \mathrm{~g} / \mathrm{mL}$, did not alter force of contractions (it was $110 \%$.) This means that atenolol may be have a negative inotropic effect, which is characteristic only for nonpregnant rats with estrogen dominance background.

The effect of adrenaline $\left(10^{-5} \mathrm{~g} / \mathrm{mL}\right)$ against atenolol $\left(10^{-6}\right.$ or $\left.10^{-8} \mathrm{~g} / \mathrm{mL}\right)$ : It was found (Table 2, Figure 1, panel B; Figure 2, panel B) that in nonpregnant and pregnant rats adrenaline on background atenolol, regardless of the concentration of blocker $\left(10^{-6}\right.$ or $\left.10^{-8} \mathrm{~g} / \mathrm{mL}\right)$ did not have a positive inotropic effect, and in some cases. Caused a negative inotropic effect. Indeed, in nonpregnant rats with estrogen dominance background force of contraction under influence of adrenaline $\left(10^{-5} \mathrm{~g} /\right.$ $\mathrm{mL})$ against atenolol was $93 \%$ from the previous stage $\left(\mathrm{p}>0.05^{\mathrm{w}}\right)$, and in rats with the dominance of progesterone is even significantly reduced (up to $85 \% *$ ), and in general, at nonpregnant rats , it was reduced to $85 \% *$. In pregnant rats on background atenolol $\left(10^{-8} \mathrm{~g} / \mathrm{mL}\right)$ the force of contraction under the influence of adrenaline reduced to $76 \%$ * In this case, all difference between groups were not statistically significant. Thus, on the background of blockade of beta ${ }_{1}$-AR by atenolol, as well as on the background of the blockade of beta $\mathrm{A}_{1}$-AR and beta - $_{2}$ AR by propranolol adrenaline instead of a positive inotropic effect exhibits a negative inotropic effect.

Effect of adrenaline $\left(10^{-5} \mathrm{~g} / \mathrm{mL}\right)$ against atenolol $\left(10^{-6}\right.$ or $\left.10^{-8} \mathrm{~g} / \mathrm{mL}\right)$ and histidine $\left(\mathbf{1 0}^{-4} \mathbf{g} / \mathbf{m L}\right)$ : Established (Table 2, Figure 1, panel B; Figure 2, panel B), that in rats with estrogen dominance addition of histidine was accompanied by a reduction of ability of adrenaline to exercise a positive inotropic effect on the background of atenolol $\left(10^{-6} \mathrm{~g} / \mathrm{mL}\right)$ - the force of contraction in these conditions significantly increased to $106 \% *$ (instead of $93 \%$ in the absence of histidine). In rat with progesterone dominance histidine on the background atenolol $\left(10^{-6} \mathrm{~g} / \mathrm{mL}\right)$ did not change the response to adrenalin - in these conditions, as in the absence of histidine force of contraction was statistically significantly lower (respectively $87 \%$ *and $85 \% *$ ) than in conditions of perfusion of only atenolol. In pregnant rats by adding histidine in the background atenolol $\left(10^{-8} \mathrm{~g} / \mathrm{mL}\right)$ adrenaline stopped to show a negative inotropic effect - under these conditions, the force of contraction amounted to $105 \%$ ( $p>0.05$ ), which was statistically significantly higher than the force of contractions before the introduction of histidine (76\%* of force, observed on the background of atenolol). Thus, the histidine at a concentration of $10^{-4} \mathrm{~g} / \mathrm{mL}$ is able to remove the negative inotropic effect of adrenaline, observed under influence of adrenaline on background 
of atenolol. It is set for myocardium of nonpregnant rats with estrogen dominance background, as well as for myocardium of pregnant rats, and even histidine able to change this effect from the negative to the positive, that found in nonpregnant rats with estrogen dominance.

C. Results of series VII (experiments with nicergoline): In this series, which was carried out only with myocardium of the nonpregnant rat as used blocker of alpha-AR nicergoline $\left(10^{-8} \mathrm{~g} / \mathrm{mL}\right)$. This series as a series III-VI, comprised of 8 stages. It showed (Table 2, Figure 1, panel B), that, regardless of the cycle phase initially adrenaline $\left(10^{-5}\right.$ $\mathrm{g} / \mathrm{mL}$ ), as in III-VI series, at 1-st test (step 2) and 2-nd test (step 8) significantly and reversibly increase the force of contraction (respectively up 126\%* and 128\% * of the previous stages). Nicergoline $\left(10^{-8} \mathrm{~g} / \mathrm{mL}\right.$, stage 4$)$, regardless of the phase of the cycle, the force of contraction has not changed - it was $97 \%$ of stage 3 . Against nicergoline $\left(10^{-8}\right.$ $\mathrm{g} / \mathrm{mL})$, i.e. while blockade of alpha ${ }_{1}$-AR and alpha ${ }_{2}$-AR adrenaline $\left(10^{-5} \mathrm{~g} / \mathrm{mL}\right.$, stage 5) does not effect on the force of contractions - in rats with the dominance of estrogen it was $89 \%$, and in rats with the dominance of progesterone - $77 \%$, and a total $-88 \%$ of stage 4 . (Changes were not statistically significant). However, in presence of nicergoline $\left(10^{-8} \mathrm{~g}\right.$ $/ \mathrm{mL})$ and histidine $\left(10^{-4} \mathrm{~g} / \mathrm{mL}\right)$, adrenaline increased force of contraction respectively up to $124 \% *$ (estrogens background) and up 113\%* (progesterone background) or in whole, to $114 \%$ * from step 4 . Thus, nicergoline, like propranolol and atenolol, leads to a loss ability of adrenaline to provide a positive inotropic effect, but, in contrast to the experiments with propranolol or atenolol, it did not lead to ability of adrenaline provide of negative inotropic effect. At the same time on the background of nicergoline histidine restored the ability of adrenaline provide a positive inotropic effect.

D. Results series VIII (experiments with a mixture of nicergoline and propranolol): This series was conducted on the same strips of myocardium of nonpregnant rats, which evaluated the effect of nicergoline (Figure 1, panel D). It consisted of 5 stages (KS $\rightarrow$ nicergoline, $10^{-8} \mathrm{~g} / \mathrm{mL}$; N8) $\rightarrow$ nicergoline, $10^{-8} \mathrm{~g} / \mathrm{mL}$; N8. + Propranolol $\left(10^{-8} \mathrm{~g} / \mathrm{mL}, \mathrm{Pr} .8\right) \rightarrow$ Pr8 + H8 + adrenaline (10-5 g /ml; Ad5) $\rightarrow$ H8+ Pr8 + Ad5 + histidine $\left(10^{-4} \mathrm{~g} / \mathrm{mL}\right)$. At the same time as the initial reaction to the adrenaline took the results of the 2 nd test of adrenaline in the series VII. Due to the small number of observations ( $n=8)$, in this phase of the cycle series disregarded. It was found (Table 2), that mixture blockers (step 3) does not effect on the force of myocardial contraction - it was $102 \%$ of stage 1 . Against the background of these two blockers (step 4), adrenaline $\left(10^{-5} \mathrm{~g} / \mathrm{mL}\right)$ did not change of contraction force of (which was $90 \%$ of stage 3 ), including at adding histidine (which was $103 \%$ of the phase 3 ). Thus, on the background of the blockade of alpha ${ }_{1}-A R$, alpha $2-A R$, beta $-A R$ and beta 2 -AR adrenaline lost its ability to increase the force of contraction, but at the same time adrenaline did not gain the ability to provide a negative inotropic effect and the histidine is not restored the ability of adrenaline to show positive inotropic effect.

\section{Discussion}

\section{Contractility of myocardium}

It is known that in women during pregnancy minute volume of blood flow, increases and hence increases pumping function of the heart [14,21]. This is due to the increase in systolic volume $[14,21]$ and the heart rate $[14,22]$. The question of the nature of increasing of systolic volume remains open. Indeed, there are few reports about the decline of contractility of myocardium of left ventricle at pregnant rat [15], or, conversely, about increase myocardial contractility during pregnancy, which is set for the left and right ventricles of rats [16]. It is also reported that during pregnancy occur hypertrophy of left ventricle in rats [16] and women [23]. We have shown that contractility of myocardium of rat right ventricle is independent of the phase of the estrous cycle, and systolic volume of heart during pregnancy, which is typical for women $[14,21]$, is a consequence of myocardial hypertrophy, and not the result of 
increasing its specific contractility. Referring directly to the main purpose of our study, we note that the information about the immutability of specific myocardial contractility during pregnancy allow for a correct assessment of the effect of adrenergic drugs and histidine on contractility of myocardium l extracted for study at different stages of the reproductive process.

\section{Adrenoreactivity of rat myocardium}

It is known [24,25], that the heart rate variability (HRV), which reflects the adrenoreactivity and cholinoreaktivity of myocardium in women during pregnancy significantly reduced $[8,22,26-28]$. It is believed to be due to the increase in sympathetic effects on the heart [28], or high content in blood of endogenous sensitizer of betaadrenoceptors (ESBAR), which increases the effectiveness of the activation of beta-AR of myocardium, i. e increases of myocardial adrenoreactivity [8,26,27].

Evaluation of adrenoreactivity of isolated myocardium of nonpregnant (including phases of the estrous cycle) and pregnant rats suggests that the decrease in HRV during pregnancy in women, in addition to the above two reasons may be due to changes of expression of adrenoceptors (including alpha ${ }_{1}-A R$, alpha $a_{2}-A R$ and beta $-A R$ ) and M-cholinergic receptors of the heart, although testing myocardium of nonpregnant and pregnant rats of adrenaline used in the near-threshold $\left(10^{-9} \mathrm{~g} / \mathrm{mL}\right)$, and abovethreshold $\left(10^{-5} \mathrm{~g} / \mathrm{mL}\right)$ concentrations did not allow us to identify statistically significant change of adrenoreactivity of isolated myocardium of right ventricle during the estrous cycle and during pregnancy/ However, when we using adrenaline in a broader set of concentrations $\left(10^{-9}, 10^{-8}, 10^{-7}, 10^{-6}\right.$ and $\left.10^{-5} \mathrm{~g} / \mathrm{mL}\right)$, we were able to show that in the middle and later stages of pregnancy, the probability of a positive inotropic effect of adrenaline drops (unpublished data).

\section{Influence blockers of AR on myocardial contractility}

We have found that propranolol $\left(10^{-8} \mathrm{~g} / \mathrm{mL}\right)$ reduced (to $87 \%$ from baseline) force of myocardial contraction of nonpregnant rats with the domination of progesterone, but it does not effect on myocard of the nonpregnant with the dominance of estrogen and also of myocardium of pregnant rats. Atenolol $\left(10^{-6} \mathrm{~g} / \mathrm{mL}\right)$ reduced (to $74 \%$ ) force of myocardial contraction of nonpregnant rats with estrogen dominance, but it does not effect on the myocardium of the nonpregnant arts with the dominance of progesterone and (at a concentration of $10^{-8} \mathrm{~g} / \mathrm{mL}$ ) of pregnant women. Nicergoline $\left(10^{-8} \mathrm{~g} / \mathrm{mL}\right)$, including together with propranolol $\left(10^{-8} \mathrm{~g} / \mathrm{mL}\right)$ did not effect on the force of contraction of nonpregnant rats, regardless of the cycle phase. Taking into account the data of the literature, we believe that in the basis of the negative inotropic effect of propranolol and atenolol may lie at least three mechanisms. The first of these the decreasing of excitability of cardiocytes, as it is known that both blockers can exert effect, which is to stabilize the plasma membrane [30]. The second mechanism - it is the activation of alpha ${ }_{1}-\mathrm{AR}$, as shown [31], that propranolol may exhibit properties of alpha1-AR- agonist. And according to our observations propranolol shows no negative inotropic effect when it acts together with nicergoline as a blocker of the alpha $\mathrm{A}_{1}$-AR. The third mechanism - this inhibition under influence of blockers ability of beta ${ }_{2}$-AR to autoactivation (i.e. activation of the Gs-protein in the absence of agonist), described in the literature [32]. We believe that future research will answer on the questions which of these three mechanisms underlies the phenomenon identified.

We found that in pregnant rats, propranolol and atenolol show no negative inotropic effect. This may be due to the fact that during pregnancy increases myocardial resistance to the negative inotropic effects of blockers of betaAR, reduced the ability of beta-AR to autoactivation and decreases the effectiveness of the activation of alpha ${ }_{1}{ }^{-}$ AR under the influence of blockers of beta-AR.

At the same time, the results of our studies indicate the possibility of using blockers 
of beta-AR (propranolol, atenolol) and blockers of alpha-AR (nicergoline) to study the mechanism of impact histidine on efficiency of signaling from adrenoceptors into intracellular effectrors

Reversion of inotropic effect of adrenaline (10-5 $\mathrm{g} / \mathrm{mL})$ at blocking of beta-AR and alpha-AR: We have shown that at blocking of beta ${ }_{1}$ AR by atenolol $\left(10^{-8}\right.$ or $10^{-6} \mathrm{~g}$ $/ \mathrm{mL})$ or at blocking of beta $-\mathrm{AR}$ and beta2- AP by propranol $\left(10^{-8} \mathrm{~g} / \mathrm{mL}\right)$, adrenaline $\left(10^{-5} \mathrm{~g} / \mathrm{mL}\right)$ instead of the positive inotropic effect shows negative inotropic effect. In particular, in nonpregnant rats on background of atenolol adrenaline reduces force of contraction to $85 \%$ of baseline, and on background of propranolol adrenaline reduces force to $70 \%$, and in pregnant rats respectively adrenaline reduced force to $76 \%$ and $82 \%$. Against on the background of the blocking of alpha ${ }_{1}$-AR and alpha $_{2}$-AR by nicergoline $\left(10^{-8} \mathrm{~g} / \mathrm{mL}\right)$ or on background of the blocking of alpha ${ }_{1}-\mathrm{AR}$, alpha $\mathrm{a}_{2} \mathrm{AR}$, beta $_{1}$-AR and beta $-\mathrm{AR}$ be mixture of nicergoline and propranolol, which assessed only in experiments with myocardial nonpregnant rats, adrenaline also lost its ability to exert a positive inotropic effect, but he no showed negative inotropic effect. Note that G Kissling et al. [33] in the experiments with the papillary muscle of the right ventricle of male rats have shown that adrenaline in concentration $5 \times 10^{-7} \mathrm{~g} / \mathrm{mL}$ on background atenolol (5x10-5 g / mL), as in our experiments, instead of a positive inotropic effect exhibits negative inotropic effect. The authors explained this phenomen by activation of alpha ${ }_{1}$-AP. However according A.S.Chinkin [34], in experiments with rats myocardial strips of right atrial adrenaline on the background of propranolol $\left(10^{6} \mathrm{~g} / \mathrm{mL}\right)$ continues to exert a positive inotropic effect. According to this author [34], in the conditions of blocking of beta ${ }_{1}$ AR and beta ${ }_{2}$-AR adrenaline activates the alpha1-AR, which causes an increase in contractility. In explaining the identified negative inotropic effect of adrenaline $\left(10^{-5} \mathrm{~g} / \mathrm{mL}\right)$ against the background of blocking of beta-AR by propranolol or by atenolol, we proceed from the idea myocardiocites of mammals besides beta ${ }_{1}$ AR and beta $^{2}-\mathrm{AR}$, which at activation, usually increases of contractility $[35,36]$, contain beta ${ }_{3}$ $\mathrm{AR}$, alpha ${ }_{1}$-AR and alpha ${ }_{2}$-AR (as autoreceptors), activation of which may decrease of contractility/ Is installed in respect of beta ${ }_{3}-\operatorname{AR}[37,38]$, alpha ${ }_{1}$-AR $[39,40]$ and alpha ${ }_{2}$ AR as an autoreceptor [41,42], although activation of alpha ${ }_{2}$-AR can be accompanied by increasing of contractility $[43,44]$. In the literature also observed that propranolol can block the beta - AR [45], although according to other sources, propranolol does not block these receptors [46]. It is also known that the contractility of myocardium can decrease under the influence of NO, which is produced by cardiomyocytes $[47,48]$, as well as contractility of myocardium can decrease under the activation of serotonin receptor types 5-HT1A and 5-HT2A/C [49], including, probably under the influence of nicergoline, which, is known [50], is derived ergot With all these data, we can give the following interpretation of the phenomena identified in our experiments. 1) Under the conditions of the blocking of beta ${ }_{1}-\mathrm{AR}$ by atenolol adrenaline activates the beta ${ }_{2}-\mathrm{AR}$, beta $_{3}-\mathrm{AR}$, alpha $\mathrm{A}_{1}-\mathrm{AR}$ and alpha ${ }_{2}-\mathrm{AR}$, and the positive effect of adrenaline due to activation of beta ${ }_{2}-\mathrm{AR}$ and possibly alpha ${ }_{2}-\mathrm{AR}$ is much weaker than the negative effect that occurs when activating of beta ${ }_{3}-\mathrm{AR}$ and alpha $_{1}-\mathrm{AR}$. Therefore, the action of adrenaline observed negative inotropic effect. This may contribute to increasing of production of NO under the influence of adrenaline. 2) In the conditions of the blocking of beta ${ }_{1 .} \mathrm{AR}$ and beta $_{2}-\mathrm{AR}$ and possibly beta ${ }_{3}$-AR by propranolol adrenaline activates the alpha ${ }_{1}$ $\mathrm{AR}$ and alpha ${ }_{2}-\mathrm{AR}$; wherein the positive effect due to possible activation of alpha ${ }_{2}-\mathrm{AP}$ becomes weaker than the negative inotropic effect caused by activation of alpha ${ }_{1}$-AR and possibly by activation of beta ${ }_{3}$-AR. For this reason, the action of adrenaline on the background of propranolol observed as a negative inotropic effect. It can also contribute to increasing of the production of NO u nder the influence of adrenaline. The absence of the negative effect of adrenaline at blocking receptor with mixture of nicergoline and propranolol confirms the idea that the manifestation of negative inotropic effect of adrenaline on the background of propranolol caused primarily by activation of alpha ${ }_{1}^{-}$ AP. 3). In the conditions of the blocking of alpha ${ }_{1}-A R$, and (to a lesser extent), alpha ${ }_{2}$ - 
AR by nicergoline adrenaline activates the beta ${ }_{1}-\mathrm{AR}$, beta ${ }_{2}$-AR and beta3-AR, that must be accompanied by a positive inotropic effect. However, in reality this effect is not observed in spite of the presence of "intact" beta 1 -AR and beta 2 -AR. This phenomenon can be explained, first of all, on the assumption that nicergoline not only blocks alpha ${ }_{1}^{-}$ $\mathrm{AR}$ and alpha 2 -AR, but also nonselectively blocks beta ${ }_{1}-\mathrm{AR}$, and in the second, taking into account the concepts about nicergoline as a derivative of ergot [47], we suggests that in itself nicergoline activates serotonin receptors of the 5-HT1A and 5-HT2A / C, that reduces myocardial contractility [46].

Thus, in general, the question of the nature of the negative inotropic effect of adrenaline on the background of the blocking of beta - AR with propranolol and atenolol, as well as the absence of a positive effect of adrenaline on the background of nicergoline requires further investigation, as identified phenomenas have, in our view, the clinical orientation.

Effect of histamine on the force of evoked contractions of myocardium of nonpregnant and pregnant rats: We have found that histidine $\left(10^{-10}-10^{-4} \mathrm{~g} / \mathrm{mL}\right)$ does not effect on force of evoked contractions of myocardium of nonpregnant rats with the domination of their estrogen, but it tends to increase (up to $110-119 \%$ of baseline) at nonpregnant rats with the dominance of progesterone. At the same time, histidine significantly increases the force of contraction (up to 110 - 130\% of background level) in pregnant rats, although this effect was independent of concentration of histidine in the medium. These data indicate that the ability histidine exhibit a positive inotropic effect on the myocardium of the rat right ventricle increase under the influence of progesterone. Previously, was found the ability of histidine $\left(10^{-4}\right.$ and $\left.10^{-3} \mathrm{~g} / \mathrm{mL}\right)$ increase the force of myocardial contractions of strips of the right ventricle of female rats (up to $125 \%$ of background) [7], as well as the ability of histidine $\left(10^{-5} \mathrm{~g} / \mathrm{mL}\right.$ ) increases of force of contractions (up to 133\%) of biopsies myocardium from ear of hearts of people undergoing aorto-coronary bypass surgery $[9,10]$.

These data allow us to conclude that, indeed, histidine, under certain conditions, is able to exert a positive inotropic effect, which contributes to high levels of progesterone, as well as reduced (for whatever reason) the functional state of the myocardium. We assume that the positive inotropic effect of histidine may be due to its ability to activate specific histidine receptors of myocardiocytes, thereby changing the activity of one or more of Ca-transporting mechanisms. As is known, these include receptor-operated and voltage-operated Ca-channels; Ca channels, operated Ca-depo; ryanodine-sensitive and inositolthriphosphat- sensitive channels of the sarcoplasmic reticulum (SR); Ca-pump of the plasma membrane; Ca-pump of SR (SERCA) and Na-Ca exchange mechanism. At the same time we do not exclude that kind of Ca-transporting mechanism that changes its activity under the influence of histidine depends on the concentration of histidine. Obviously, in cases where there is some malfunction of the Ca-transporting mechanisms, histidine (as a kind of "chaperone") causes their repair and thereby restores their function. All this underlines the importance of and the clinical prospects for further study of the nature of the positive inotropic effect of histidine.

Influence of histamine on the contractile effects of near-threshold and above the threshold concentrations of adrenaline, including the presence of adrenoblockers of in the environment We have shown that in the experiments with intact myocardium strips of nonpregnant and pregnant rat histidine at concentrations $10^{-10}-10^{-4} \mathrm{~g} /$ $\mathrm{mL}$ did not enhance the ability of adrenaline used in the near- threshold $\left(10^{-9} \mathrm{~g} /\right.$ $\mathrm{mL}$ ) concentrations, exert a positive inotropic effect, i.e. histidine does not exhibit beta-adrenosensibilizatory activity. Furthermore, the histidine at relatively high concentrations $\left(10^{-6}, 10^{-5}\right.$ and $\left.10^{-4} \mathrm{~g} / \mathrm{ml}\right)$ in the experiments with pregnant rat myocardium has even weak beta-adrenoblocking effect. However, under conditions in which the efficiency of activation of beta-AP artificially reduced, in particular, by 
blocker of beta - AR atenolol or by blocker of beta 1 -AR and beta 2 -AR propranolol or by blocker of alpha-AR nicergoline, histidine partially restores the effectiveness of betaAR activation. This means that histidine can exhibit beta-adrenosensibilizatory activity against rat myocardium, but with the proviso that initially beta- adrenoreactivity of myocardium artificially lowered. Earlier, a similar pattern was observed by Yu.A.Penkina et al. [7] in the experiments with female rats myocardium. In these experiments histidine at concentrations $10^{-5}, 10^{-4}$ and $10^{-3} \mathrm{~g} / \mathrm{mL}$ for the intact myocardium strips did not enhance the positive inotropic effect of adrenaline $\left(10^{-8}-10^{-6} / \mathrm{mL}\right)$, i.e. histidine showed no beta- adrenosensibilizatory activity and at a concentration of $10^{-3} \mathrm{~g}$ mL exerted weak beta-adrenoblocking effect with respect to adrenalin in a concentration of $10^{-6} \mathrm{~g} / \mathrm{mL}$. At the same time on myocardial strips which efficiency of beta-AR activation was reduced by lysophosphatidylcholine (LPC, $10^{-5} \mathrm{~g} / \mathrm{ml}$ ), histidine $\left(10^{-5}-10^{-3} \mathrm{~g} / \mathrm{mL}\right.$ ) restored efficiency of beta-AR activation even in the presence of LPC [7]. In experiments with rat myometrium, which is the dominant population of beta ${ }_{2}$-AR was shown $[3,5,6,51]$, that histidine increases the efficiency of activation of beta-AP of "intact" myometrium $[3,6,51]$ and myometrium, $y$ whose effectiveness of beta ${ }_{2}$-AR activation was reduced by LPC $\left(10^{-5} \mathrm{~g} / \mathrm{mL}\right)$ or by propranolol $\left(10^{-9}-10^{-6} \mathrm{~g} / \mathrm{mL}\right)[5,6]$.

In explaining the identified phenomenon we have we proceeded from the position that the rat cardiomyocytes besides beta $-\mathrm{AR}$ and beta ${ }_{2}-\mathrm{AR}$ contain beta ${ }_{3}-\mathrm{AR}$, the activation of which is known $[37,38]$, decreased contractility of myocardium. We assume that the histidine is able to improve the efficiency of activation of all three populations of beta$\mathrm{AR}$, including the beta ${ }_{3}-\mathrm{AR}$. Therefore, the lack of ability of histidine enhance positive inotropic effect of adrenaline in experiments with intact myocardium (as opposed to the myometrium, which is dominated by the population of beta ${ }_{2}-\mathrm{AR}$ ), we explain the fact that histidine, increasing the effectiveness of activation of beta ${ }_{1}-\mathrm{AR}$ and beta $_{2 .} \mathrm{AR}$, providing positive inotropic effect of adrenaline, simultaneously improves the efficiency of activation and beta ${ }_{3}-\mathrm{AR}$, and thus contributes to the manifestation of the negative inotropic effect of adrenaline. Therefore eventually histidine at the intact myocardium does not enhance positive inotropic effect of adrenaline, i.e. does not exhibit betaadrenosensibilizatory activity, or (where expression of beta ${ }_{3}$-AR is increased, probably typical for pregnant rat myocardium) even reduces force of contraction that exhibits beta-adrenoblocking activity. In the conditions of the blocking beta ${ }_{2}$-AR by propranolol and /or beta ${ }_{1}$ AR (atenolol or propranolol) adrenaline activates alpha ${ }_{1}-\mathrm{AR}$, alpha $\mathrm{A}_{2}$-AR and beta ${ }_{3}-\mathrm{AR}$ and thereby causes a negative inotropic effect. In these conditions histidine also increases the efficiency of activating all three populations of beta-AR but, obviously, is particularly important in the effectiveness of the activation of beta ${ }_{1}-\mathrm{AR}$ and beta ${ }_{2}$-AR and thereby ensure the implementation of the positive inotropic effect of adrenaline. The consequence is the blockage of negative inotropic effect of adrenaline which induced histidine. Obviously, complete restoration of ability of adrenaline to show positive inotropic effect prevents activation of beta ${ }_{3}-\mathrm{AR}$, also increases the presence of histidine.

As noted above, on a background of nicergoline as blockers of alpha ${ }_{1}-\mathrm{AR}$ and alpha ${ }_{2}$-AR adrenaline $\left(10^{-5} \mathrm{~g} / \mathrm{mL}\right)$ ceased to provide a positive inotropic effect. This we explain 1) ability of nicergoline to activate serotonin receptors such as 5-HT1A and 5-HT2A / C, and thereby induce a negative inotropic effect, as well as 2) the ability of nicergoline to partially block beta ${ }_{1}-\mathrm{AR}$ and beta $_{2}$-AR. Against the background of nicergoline histidine restored the ability of adrenaline to show positive inotropic effect. This can be explained by an increase effectiveness of activation of beta-AR (primarily beta $_{1}-\mathrm{AR}$ and beta ${ }_{2}-\mathrm{AR}$ ) under the influence of histidine/ this on the background of the continuing blockade of alpha ${ }_{1}$-AR leads to an increase in force of cjntractions.

As we have noted, against the blockade of alpha ${ }_{1}-A R$ and $\operatorname{lpha}_{2}-A R$ by nicergoline, and the blockade of beta $-\mathrm{AR}$ and beta $^{2}$-AR by propranolol, adrenaline does not change the effect of myocardial contraction. In these conditions, histidine does not restore the positive inotropic effect of adrenaline. Obviously, that the negative inotropic effect, 
which due to the activation of serotonin receptors type 5-HT1A and type 5-HT2A /C under the influence of nicergoline and also due to the activation of beta 3 -AR, enhanced histidine prevented manifest of positive inotropic effect produced upon activation beta $_{1}$-AR and beta 2 -AR enhanced by histidine.

Thus, the results of experiments with nicergoline or with a mixture of "nicergoline+ propranolol" does not contradict the basic concept that histidine is a factor that increases the efficiency of the activation of all the populations of the beta-AR.

The mechanism of action of histidine as a factor that increases the efficiency of the activation of beta-AR of cardiomyocytes, including the occupation of beta ${ }_{1}$ AR or/ and beta ${ }_{2}$-AR by its blockers. Earlier in the works of our laboratory, it was suggested three proposals to explain the mechanism of action of endogenous sensitizer of betaadrenoceptors (ESBAR) and its analogs, including histidine.

According to the first assumption, beta 2 -AR and probably beta 1 -AR contain specific allosteric site. Occupation this site by ESBAR or by its analogs -histidine, tryptophan, tyrosine or mildronate (trimethylhydrazinium propionate) - increases the affinity of receptors to adrenaline [51].

According to the second assumption, ESBAR and its analogs, including histidine improve efficiency of activation of beta ${ }_{1}$-AR and beta $_{2}$-AR due to repair disorders that occur in one or more transmission units from these receptors to intracellular effectors during prolonged operation of system «agonist-adrenoceptors» or in the presence of damaging agents in the environment, for example, lysophosphatidylcholine (LPC) [7]. In other words, ESBAR or its analogs, including histidine is regarded as an extracellular and / or intracellular "chaperone", which reduce efficiency transmission of signal with "downstream".

According to the third proposal, ESBAR and its analogs, including histidine, in addition to the functions of allosteric modulator and intracellular "chaperone" simultaneously activated phosphatase, thus amplified dephosphorylation of beta ${ }_{1}$-AR and beta ${ }_{2}$-AR and restoring the conformation of this AR [6].

We share these three views, but we offer this list to add two more assumptions (fourth and fifth) of the possible mechanisms by which ESBAR and its analogs increase the efficiency of the activation of beta-AR, including background blockers of beta-AR, which allows adrenaline effectively to compete with these blockers for the binding site of the receptor.

According to fourth proposal ESBAR and its analogs can promote the formation of oligomers of beta-AP, which improves efficiency of transmission from the receptors to G-proteins. Actually, in the literature reported [52], that the efficiency of transmission of signal from receptors associated with G-protein, is increased, if previously activated receptor agonist forms oligomers, which triggering transduction of signal with "downstream".

According to the fifth assumption, ESBAR and its analogs, including histidine, can inhibit kinase of beta-AR and/ or inhibit the interaction of beta-arrestin with beta$\mathrm{AR}$, whereby the rate of development of desensitization of these receptors is reduced, which, in turn, increases the efficiency of activation of beta-AR. In this respect, important data of $\mathrm{H}$ Brinks et al. [53] about the existence of an endogenous peptide (beta-ARKct), dimer binding $\mathrm{G}$ beta-gamma, thus preventing the activation of the kinase of beta-AR. Great interest are also data of Q. Wang et al. [54] about an endogenous antagonist of GRK2-beta arrestin signaling This is protein spinophilin, blocking the interaction of beta-arrestin with beta-AR and other receptors associated with G-proteins, and thus prevents the development of desensitization. 
There is no doubt that further research should be aimed at the study of all of these (at least five) the possible mechanisms underlying the increase of efficiency of the activation of beta ${ }_{1}$-AR and beta $_{2}$-AR under influenced of ESBAR and its analogs, including histidine. This suggests that histidine and other exogenous analogs of ESBAR like peptide beta-ARKct. [53], will be used in clinical cardiology.

The clinical significance of the phenomenon of manifestation of the negative

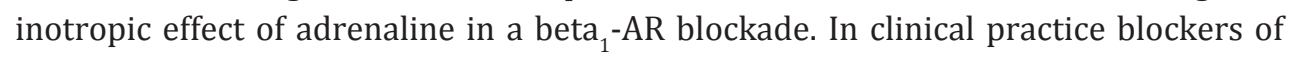
beta $_{1}-\mathrm{AR}$, as it is known [55], are used to reduce the positive inotropic and chronotropic effects of catecholamines, including in patients with hypertension, arrhythmias of various origins, as well as to reduce the death myocardiocytes by apoptosis or necrosis and for reducing the severity of pathological cardiac hypertrophy. It is obvious that against the background of normal levels of catecholamines in the blood and the normal state of the sympathetic nervous system such blockade does not lead to the development of cardiac weakness. However, we believe that in stressful situations in which content of catecholamines instantly increases in blood to high values and also instantly enhanced activity of the sympathetic nervous system, instead of the expected gains in force of heart contractions in the background of the blockade beta - $_{1}$ AR due to the negative inotropic effect of catecholamines (as is the case in our experiments) may occur reduction of force of heart contractions. This can lead to the development of acute heart failure. Therefore, in these conditions it is important prevention of such a condition. Our findings suggest that as a measure of prevention of negative inotropic effects of catecholamines on the background blocking of beta ${ }_{1}$-AR can be used analogs of ESBAR, i/e, exogenous sensitizers of beta-AP, including mildronate, or one of the aromatic amino acids - histidine, tryptophan or tyrosine. Many years of clinical observations using of mildronat together with the blockers of beta ${ }_{1}$-AR for example at patient with myocardial infarct, demonstrates clinical benefit [56]. In the cardiology made to explain the feasibility of mildronat its metabolic effect, improves energy of myocardium [56]. However, in our view, a positive effect of mildronat may also be due to the fact that in the conditions of application blocker of beta ${ }_{1}$-AR is partially restores the efficiency activation of beta ${ }_{1}-\mathrm{AR}$ and beta $^{2}-\mathrm{AR}$ and thus prevents the development of negative inotropic effect of catecholamines as mediators and as hormonal origin.

Thus, our results suggest the feasibility of using of mildronat and other analogs of ESBAR in cardiology practice at patients with chronic heart failure, in which, as is well known [57], reduced the effectiveness of the activation of beta-AR, as well as in obstetrics to improve the effectiveness of beta -adrenoceptors inhibitory mechanism in pregnant women $[5,6]$. The results of our experiments also point to the need to find selective sensitizers of beta ${ }_{1}-\mathrm{AR}$, beta b $_{2} \mathrm{AR}$ and beta $_{3}-\mathrm{AR}$.

\section{Conclusions}

In experiments with myocardial stripes of the right ventricle of nonpregnant and pregnant rats it found:

1. Histidine $\left(10^{-10}-10^{-4} \mathrm{~g} / \mathrm{ml}\right)$ does not increase the force of induced contractions of myocardial of the nonpregnant rats, but it increases (regardless of concentration) contractions of myocardial of the pregnant rats.

2. Histidine $\left(10^{-10}-10^{-4} \mathrm{~g} / \mathrm{mL}\right)$ does not increase the contractile response of intact myocardial strips of nonpregnant and pregnant rats under influence of adrenaline in near-threshold concentrations $\left(10^{-9} \mathrm{~g} \mathrm{~mL}\right)$, ie histidine does not exhibit beta-adrenosensibilizatory activity.

3. Adrenaline in high (up-threshold) concentrations $\left(10^{-5} \mathrm{~g} / \mathrm{mL}\right)$ when subjected to isolated myocardium of nonpregnant and nonpregnant rats causes a positive inotropic effect, but this effect was lost at the background of propranolol $\left(10^{-8}\right.$ 
$\mathrm{g} / \mathrm{mL})$, atenolol $\left(10^{-8}, 10-6 \mathrm{~g} / \mathrm{mL}\right)$, nicergoline $\left(10^{-6} \mathrm{~g} / \mathrm{mL}\right)$ and the mixture of nicergoline $\left(10^{-6} \mathrm{~g} / \mathrm{mL}\right)$ and propranolol $\left(10^{-8} \mathrm{~g} / \mathrm{mL}\right)$, while against the backdrop of propranolol or atenolol positive inotropic effect of adrenaline is reversed to the negative inotropic effect.

4. Histidine $\left(10^{-4} \mathrm{~g} / \mathrm{mL}\right)$ prevents the appearance of the negative effect of adrenaline $\left(10^{-5} \mathrm{~g} / \mathrm{mL}\right)$ against the backdrop of propranolol or atenolol, and against the backdrop of nicergoline histidine partially restores ability of adrenaline to exert a positive inotropic effect.

5. Histidine has beta-adrenosensibilizatory activity against to rat myocardium and is a useful antagonist of beta-adrenergic blockers. Therefore, the question about clinical applications of histidine and other exogenous analogs of ESBAR in clinical practice deserves further study

\section{Author Contributions}

Tsirkin V. wrote the paper, Nozdrachev A- discussion on the main issues of the paper, Korotaeva J. - conducting experiments, writing original articles and literature data collection, Khodyrev G.- English translation, format graphics, text revision.

Supported by state universities, which were carried out on the basis of experimental studies.

Open Access: This article is an open-access article which was selected by an in-house editor and fully peer-reviewed by external reviewers. It is distributed in accordance with the Creative Commons Attribution Non Commercial (CC BY-NC 4.0) license, which permits others to distribute, remix, adapt, build upon this work noncommercially, and license their derivative works on different terms, provided the original work is properly cited and the use is non-commercial.

See: http://creativecommons.org/licenses/by-nc/4.0/

\section{References}

1. Nozdrachev AD, Tumanova TV, Dvoryanskij SA, Tsirkin VI, Darmov IV, et al. Activity of a series of amino acids as potential sensitizers of smooth muscle beta-receptors. Dokl Akad Nauk 1998; 363: 133-136. Ref.: https://goo.gl/bxgV9L

2. Sizova EN, Tsirkin VI, Tumanova TV. Influence of amino acids alimentary on contracts ability in beta-adrenoand M-cholinoreactivity of smooth muscles. Vopr Pitan 2008; 77: 26-32. Ref.: https://goo.gl/YJ3GC4

3. Tumanova TV, Sizova EN, Tsirkin VI. Ability of L-histidine to decrease desensitization of the myometrium to epinephrine. Bull Exp Biol Med. 2004; 138: 321-324. Ref.: https://goo.gl/zVrZct

4. Sizova EN, Tsirkin VI, Kostyaev AA. Effect of ozone exposure on contractile activity and chemoreactivity of uterus horns longitudinal muscles of nonpregnant rats. Ross Fiziol Zh Im I M Sechenova 2003; 89: 427-435. Ref.: https://goo.gl/FXJ6Re

5. Toropov AL, Nozdrachev AD, Tsirkin VI. Investigation of the mechanism of action of endogenous sensitizer of beta-adrenoceptor (ESBAR) and its analogs. Vestnik Sankt-Peterburgskogo universiteta, Ser. 3 (biologiya) 2011; 427-423.

6. Tsirkin VI, Nozdrachev AD, Toropov AL. An endogenous sensitizer of $\beta$-adrenergic receptors and its analogs in the experiments with rat myometrium reduce the $\beta$-adrenoblocking effect of obzidan. Dokl Biol Sci 2010; 435: 375-380. Ref.: https://goo.gl/G1bzAb

7. Penkina YuA, Nozdrachev AD, Tsirkin VI. Effect of human blood serum, histidine, tryptophan, tyrosine, mildronat and lysophosphatidylcholine on inotropic effect of adrenaline in the experiments with the frog and rat myocardium. Vestnik Sankt-Peterburgskogo universiteta. Seriya 3 (Biologiya) 2008; (1): 55-68.

8. Tsirkin VI, Sizova EN, Kajsina IG, Kononova TN, Trukhin AN, et al. Heart rate variability during puberty and pregnancy. Rossijskij vestnik akushera-ginekologa 2004; (2): 4-9.

9. Korotaeva KN, Nozdrachev AD, Vyaznikov VA, Tsirkin VI. Effect of tyrosine, histidine, tryptophan, mildronat and human serum on the amplitude of caused contractions of human cardiomyocytes and inotropic effect of adrenaline. Vestnik Sankt-Peterburgskogo universiteta. Ser. 3 (biologiya) 2011; (2): 45-57. 
10. Korotaeva KN, Tsirkin VI, Vyaznikov VA. Positive inotropic effect of tyrosine, histidine, and tryptophan in experiments on isolated human myocardium. Bull Exp Biol Med 2012; 153: 51-53. Ref.: https://goo.gl/XW77dK

11. Trukhin AN, Tsirkin VI, Sizova EN. Histidine increases beta-adrenoreactivity of myocardium in frogs Bull Exp Biol Med 2004; 138: 123-126. Ref.: https://goo.gl/BBxMsV

12. Wehling M. [Pharmacology of beta blockers and their significance for therapy of hypertension]. [Article in German] Herz. 2002; 27 (Suppl 1):16-25. Ref.: https://goo.gl/9t7xQx

13. Siryk-Bathgate A, Dabul S, Lymperopoulos A. Current and future Gprotein-coupled receptor signaling targets for heart failure therapy. Drug Des Devel Ther 2013; 7: 1209-1222. Ref.: https://goo.gl/T9d9fe

14. Shechtman MM. Guide extragenital pathology in pregnant women. Moskva: Triad 2011; 896.

15. Elzwiei F, Bassien-Capsa V, St-Louis J, Chorvatova A. Regulation of the sodium. Exp Physiol 2013; 98: 183-192.

16. Virgen-Ortiz A, Marin JL, Elizalde A, Castro E, Stefani E, et al. Passive mechanical properties of cardiac tissues in heart hypertrophy during pregnancy. JPhysiol Sci 2009; 59:391-396. Ref.: https://goo.gl/BfFM4D

17. Kirshenblat YaD. Workshop on endocrinology. Moskva: Vysshaya shkola, 1969. 256.

18. Dyban AP, Puchkov VF, Baranov VS. Laboratory mammals: mouse (Mus musculus), rat (Rattus norvegicus), rabbit (Oryctolagus cuniculus), hamster (Cricetus grisous) // Ob"ekty biologii razvitiya. Moskva: Nauka, 1975. S. 505-566. Ref.: https://goo.gl/PDgjSq

19. Glantz S. Biomedical Statistics. Moskva: Praktika, 1999. 459.

20. Flores A, Velasco J, Gallegos AI, Mendoza FD, Everardo PM, et al. Acute effects of unilateral sectioning the superior ovarian nerve of rats with unilateral ovariectomy on ovarian hormones (progesterone, testosterone andestradiol) levels vary during the estrous cycle. Reprod Biol Endocrinol 201 1; 9: 34 . Ref.: https://goo.gl/RKjZj1

21. Ouzounian JG, Elkayam U. Physiologic changes during normal pregnancy and delivery. Cardiol Clin 2012; 30: 317-329. Ref.: https://goo.gl/fg78Ht

22. Dmitrieva SL, Khlybova SV, Khodyrev GN, Tsirkin VI. Condition of the autonomic nervous system in women on the eve of term labor, in the latent phase of labor and the postpartum period and the pattern of labor contractile activity. Rossijskij vestnik akushera-ginekologa 2012; (2): 12-17.

23. Umar S, Nadadur R, lorga A, Amjedi M, Matori H, et al. Cardiac structural and hemodynamic changes associated with physiological heart hypertrophy of pregnancy are reversed postpartum. $J$ Appl Physiol 2012; 113: 1253-1259. Ref.: https://goo.gl/cBLiV8

24. Baevsky RM. Analysis of HRV in space medicine Fiziologiya cheloveka 2002; 28: 70-82.

25. Dmitrieva SL, Khlybova SV, Khodyrev GN, Tsirkin VI. Heart rate variability at different stages of gestation Kirov: KOGUZ «Medicinskij informacionno-analiticheskij centr» 2013; 1-132.

26. Khlybova SV, Tsirkin VI, Dvoryanskij SA, Makarova IA, Trukhin AN. Heart rate variability in normal and complicated pregnancies. Fiziol Cheloveka 2008; 34: 97-105. Ref.: https://goo.gl/CVePfj

27. Khodyrev GN, Nozdrachev AD, Dmitrieva SL, Khlybova SV, Tsirkin VI, et al. Heart rate variability in women at different stages of the reproductive process. Vestnik Sankt-Peterburgskogo universiteta. Seriya 3. (biologiya) 2013; (2): 70-86.

28. Pöyhönen-Alho $M$, Viitasalo $M$, Nicholls $M G$, Lindström $B M$, Väänänen $H$, et al. Imbalance of the autonomic nervous system at night in women with gestational diabetes. Diabet Med 2010; 7: 988994. Ref.: https://goo.gl/uKwviT

29. Avakian ON. Pharmacological regulation of adrenergic function. Moskva: Medicina 1988; 256.

30. Bralet J, Didier J, Moreau D, Opie LH, Rochette L. Effect of alpha-adrenoceptor antagonists (phentolamine, nicergoline and prazosin) on reperfusion arrhythmias and noradrenaline release in perfused rat heart. Br J Pharmacol 1985; 84: 9-18. Ref.: https://goo.gl/73yVjb

31. Boismare F, Moore N, Decourt S, Paux G, Saligaut C, Chretien P. Potentiation by an alphaadrenolytic agent, nicergoline, of the ardiac effects of propranolol. Methods Find Exp Clin Pharmacol 1983; 5: 83-88. Ref.: https://goo.gl/DQ3p2K

32. McGraw DW, LiggettSB. Molecular mechanisms of beta ${ }_{2}$-adrenergic receptor function and regulation. Proc Am Thorac Soc 2005; 2: 292-296. Ref.: https://goo.gl/tTket5 
33. Kissling G, Blickle B, Ross C, Pascht U, Gulbins E. alpha,-adrenoceptor-mediated negative inotropy of adrenaline in rat myocardium. J Physiol 1997; 499 (Pt 1): 195-205. Ref.: https://goo.gl/WbZTpX

34. Chinkin AS. Alpha,-adrenergic receptors of the heart Pedagogiko-psihologicheskie i medikobiologicheskie problemy fizicheskoj kul'tury i sporta 2006; 1: 1-30.

35. Lefkowitz RJ. Historical review: a brief history and personal retrospective of seventransmembrane receptors. Trends Pharmacol Sci 2004; 25: 413-422. Ref.: https://goo.gl/K7bg91

36. Pérez-Schindler J, Philp A, Hernandez-Cascales J. Pathophysiological relevance of the cardiac B2-adrenergic receptor and its potential as a therapeutic target to improve cardiac function. Eur $\mathrm{J}$ Pharmacol 2013; 698: 39-47. Ref.: https://goo.gl/tQjjHU

37. Gauthier C, Rozec B, Manoury B, Balligand JL. Beta-3 adrenoceptors as new therapeutic targets for cardiovascular pathologies. Curr Heart Fail Rep 201; 8: 184-192. Ref.: https://goo.gl/KS3hah

38. Niu X, Watts VL, Cingolani OH, Sivakumaran V, Leyton-Mange JS, et al. Cardioprotective effect of beta ${ }_{3}$-adrenergic receptor agonism: role of neuronal nitric oxide synthase. J Am Coll Cardiol 2012; 59: 1979-1987. Ref.: https://goo.gl/VMnTSA

39. Chu C, Thai K, Park KW, Wang P, Makwana O, et al. Intraventricular and interventricular cellular heterogeneity of inotropic responses to $\mathrm{a}_{1}$-adrenergic stimulation. Am J Physiol Heart Circ Physiol 2013; 304: H946-H953. Ref.: https://goo.gl/VsQySQ

40. Kim JS, Kang HS, Kim JS. Alpha,-adrenoceptor-mediated negative inotropic effect caused by intracellular ionic activities in guinea-pig papillary muscle. J Vet Med A Physiol Pathol Clin Med 2005; 52: 498-505. Ref.: https://goo.gl/zevjb2

41. Porter AC, Svensson SP, Stamer WD, Bahl JJ, Richman JG, et al. Alpha-2 adrenergic receptors stimulate actin organization in developing fetal rat cardiac myocytes. Life Sci 2003; 72: 1455-1466. Ref.: https://goo.gl/jh5gEc

42. Gilsbach R, Hein L. Are the pharmacology and physiology of a-adrenoceptors determined by a-heteroreceptors and autoreceptors respectively? $\mathrm{Br} \mathrm{J}$ Pharmacol 2012; 165: 90-102. Ref.: https://goo.gl/USnFRz

43. Indolfi C, Piscione F, Villari B, Russolillo E, Rendina V, et al. Role of alpha 2-adrenoceptors in normal and atherosclerotic human coronary circulation. Circulation 1992; 86: 1116-1124. Ref.: https://goo.gl/QcBi8z

44. Woodiwiss AJ, Honeyman TW, Fenton RA, Dobson JG Jr. Adenosine A2a-receptor activation enhances cardiomyocyte shortening via $\mathrm{Ca}^{2+}$-independent and dependent mechanisms. Am J Physiol 1999; 276 (5 Pt 2): H1434- H1441. Ref.: https://goo.gl/Qpch85

45. Tavernier G, Toumaniantz G, Erfanian M, Heymann MF, Laurent K, et al. Beta ${ }_{3}$-Adrenergic stimulation produces a decrease of cardiac contractility ex vivo in mice overexpressing the human beta $_{3}$ adrenergic receptor. Cardiovasc Res 2003; 59: 288-296. Ref.: https://goo.gl/wkdLf3

46. Sillence MN, Hooper J, Zhou GH, Liu Q, Munn KJ. Characterization of porcine beta1- and beta2adrenergic receptors in heart, skeletal muscle, and adipose tissue, and the identification of an atypical beta-adrenergic binding site. J Anim Sci 2005; 83: 2339-2348. Ref.: https://goo.gl/1dC5d7

47. Odnoshivkina YG, Petrov AM, Zefirov AL. The effects of $\beta_{2}$-adrenoreceptor activation on the contractility, Ca-signals and nitric oxide production in the mouse atria. Acta Naturae 201 1; 3: 103-112.

48. Pott C, Steinritz D, Napp A, Bloch W, Schwinger RH, Brixius K. [On the function of beta3-adrenoceptors in the human heart: signal transduction, inotropic effect and therapeutic prospects]. [Article in German] Wien Med Wochenschr 2006; 156: 451-458. Ref.: https://goo.gl/Dc375U v

49. Gorini C, Jameson H, Woerman AL, Perry DC, Mendelowitz D. Prenatal nicotine exposure enhances the trigeminocardiac reflex via serotonin receptor facilitation in brainstem pathways. $J$ Appl Physiol 2013; 115: 415-421. Ref.: https://goo.gl/on96FX

50. Winblad B, Fioravanti M, Dolezal T, Logina I, Milanov IG, et al. Therapeutic use of nicergoline. Clin Drug Investig 2008; 28: 533-552. Ref.: https://goo.gl/BM2hfM

51. Sizova EN, Tsirkin VI. The physiological characteristics of the endogenous modulators of betaadreno- and M-cholinoreactivity. Kirov: Vyatskij social'no-ehkonomicheskij institut 2006: 1-183.

52. Herrick-Davis K. Functional significance of serotonin receptor dimerization. Exp Brain Res. 2013; 230: 375-386. Ref.: https://goo.gl/YyBS9A

53. Brinks $H$, Boucher M, Gao E, Chuprun JK, Pesant S, et al. Level of $G$ protein-coupled receptor kinase-2 determines myocardial ischemia/reperfusion injury via pro-and anti-apoptotic mechanisms. Circ Res 2010; 107: 1140-1149. Ref.: https://goo.gl/pL8pWs 
54. Wang Q, Zhao J, Brady AE, Feng J, Allen PB, et al. Spinophilin blocks arrestin actions in vitro and in vivo at G protein-coupled receptors. Science 2004; 304: 1940-1944. Ref.: https://goo.gl/Cu7ZpH

55. Lopatin luM, Dronova EP. [Clinical-pharmacoeconomical aspects of ß-adrenoblockers use in patients with ischemic heart disease undergoing coronary artery bypass grafting]. [Article in Russian] Kardiologiia 2010; 50: 15-22. Ref.: https://goo.gl/pf2id8

56. Gordeev IG, Liusov VA, Il'ina EE, Baiandin NL, Kuznechevskiĭ FV. [Derangements of contractility of left ventricular myocardium in patients subjected to coronary bypass surgery. Methods of their correction]. [Article in Russian] Kardiologiia 2007; 47: 22-24. Ref.: https://goo.gl/eCaHWW

57. Guggilam A, Hutchinson KR, West TA, Kelly AP, Galantowicz ML, et al. In vivo and in vitro cardiac responses to beta-adrenergic stimulation involume-overload heart failure. $\mathrm{J}$ Mol Cell Cardiol 2013; 57: 47-58. Ref.: https://goo.gl/SZpmjE 